\title{
THE CENTER FOR PLANT AND MICROBIAL COMPLEX CARBOHYDRATES AT THE UIVIVERSITY OF GEORGIA COMPLEX CARBOHYORATE RESEARCH CENTER
}

September 15, 1987-December 31, 1992

\author{
Annual Report
}

September 15, 1990-December 31, 1991

and

Fifth Year Continuation

January 1, 1992-December 31, 1992

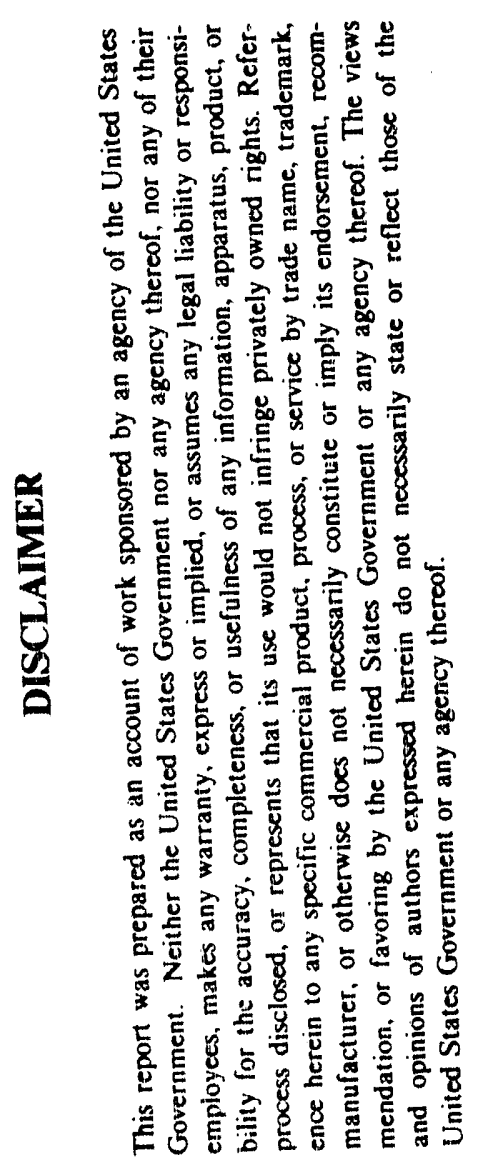

\author{
Dr. Peter Albershelm \\ and \\ Dr. Alan Darvill \\ Complex Carbohydrate Research Center \\ University of Georgla \\ Athens, GA 30602
}

August 1991

\section{MASTER}

PREPARED FOR THE

U. S. DEPARTMENT OF ENERGY

UNDER GRANT DE-FG09-87ER13810

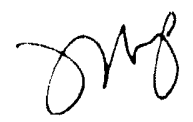

DISTHIBUTION. CF THIS DOCUMENT IS UNLIVIIIEE 


\title{
THE CENTER FOR PLANT AND MICROBIAL COMPLEX CARBOHYDRATES AT THE UNIVERSITY OF GEORGIA COMPLEX CARBOHYDRATE RESEARCH CENTER
}

\author{
Table of Contents
}

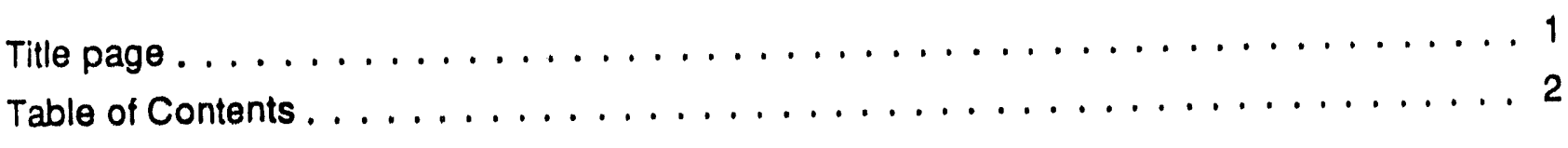

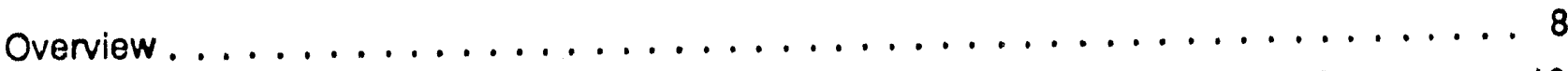

A. Collaborative Projects of the CCRC Sponsored by the Plant Science Center Grant . . . . 10

1. Structural determination of soybean isoflavones which specifically induce

Bradyrhizobium japonicum nodD1 but not the nodYABCSUIJ operon . . . . . . . . . 10

2. Structural analysis of the lipopolysaccharides (LPSS) from symbiotic niutants of

Bradyrhizobium japonicum . . . . . . . . . . . . . . . . . . . . . . . . 10

3. Structural characterization of lipooligosaccharides from Bradyrhizobium

japonicum that are required for the specific nodulation of soybean . . . . . . . . . . 11

4. Siructural characterization of the LPSs from $R$. Leguminosarum biovar phaseoli,

the symbiont of bean

5. Characterization of bacteroid-specific LPS epitopes in R. leguminosarum

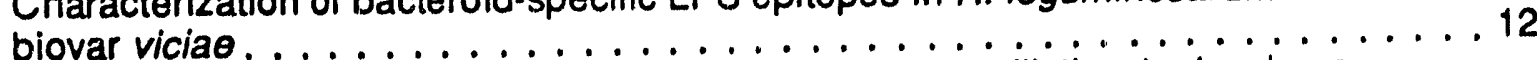

6. Analysis of the surface polysaccharides of Rhizobium meliloti mutants whose

lipopolysaccharides and extracellular polysaccharides can have the same function

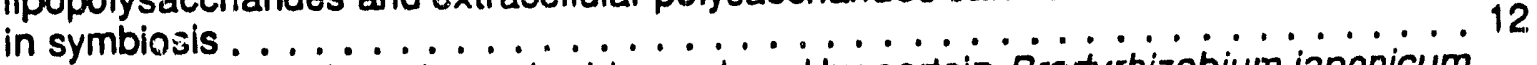

7. Characterization of a polysaccharide produced by certain Bradyrhizobium japonicum strains within soybean nodules . . . . . . . . . . . . . . . . . 13

8. Structural analysis of a streptococcal adhesin polysaccharide receptor . . . . . . . . 14

9. Conformational studies of xyloglucan. The role of the fucosylated side chain in surface-specific cellulose-xyloglucan interactions . . . . . . . . . . . . . . 14

10. The structure of an acylated glucosamine oligosaccharide signal molecule (nod factor) involved in the symbiosis of Rhizobium leguminosarum biovar viciae with

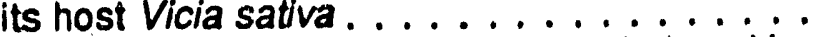

11. Investigating membrane responses induced by oligogalacturonides in cultured cells . 16

12. The polygalacturonase inhibitor protein . . . . . . . . . . . . . . . 17

13. Characterization of the self-incompatibility glycoproteins from Petunia hybrida . . . . 19

14. Investigation of the cell wall polysaccharide structures of Arabidopsis thaliana . . . . 19

15. The glucan inhibition of virus infection of tobacco . . . . . . . . . . . . 20

B. Summaries of Student Research Projects Supported by the Center Grant . . . . . . . . 21

1. Mark D. Spiro . . . . . . . . . . . . . . . . . . . . 21

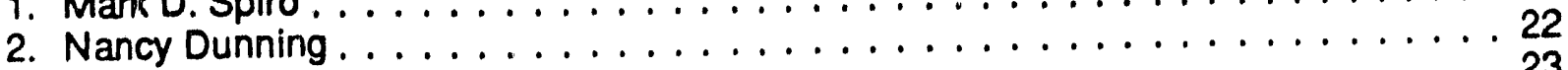

3. Que Guo . . . . . . . . . . . . . . . . . . . . . . . . . 23

4. Steven Doares . . . . . . . . . . . . . . . . . . . . . . .

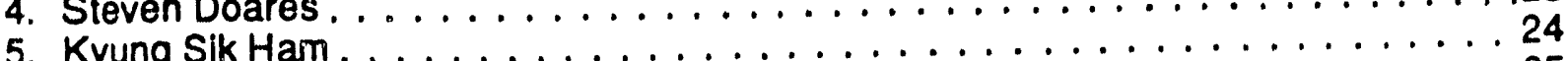

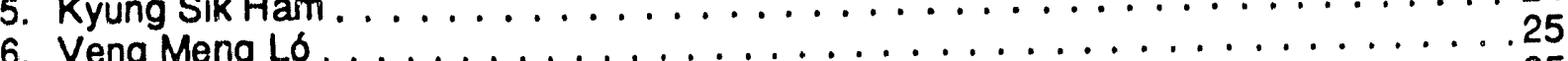

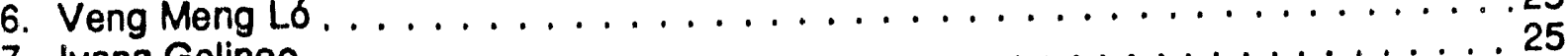

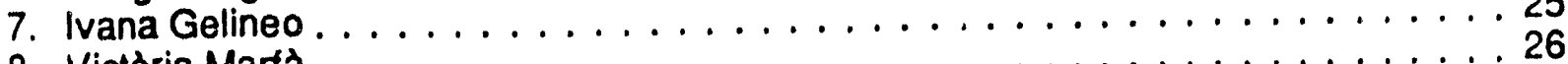

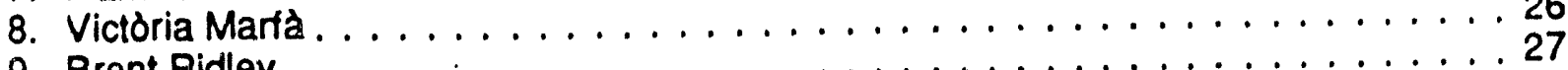

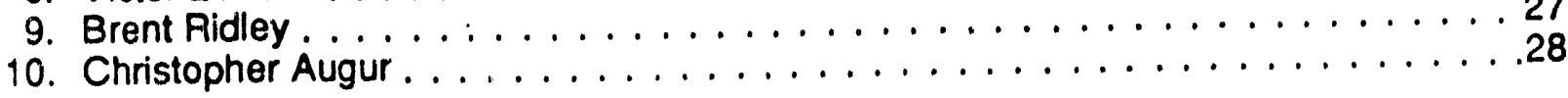


Appendices:

Appendix I: $\quad$ Publications and Abstracts of Presentations of CCRC Research Citing Center Grant Support

Appendix II: Abstracts of Publications Resulting from Collaborative Projects and Citing Center Grant Support

Appendix III: Summary of Training Courses Participants in the Training Courses

Course Evaluation Questionnaire for 1991 Training Courses

Summaries of Course Evaluation Responses

Appendix IV: Summary of Analytical Services

CCRC Charges for Analytical Services

Analysis Requests and Reports from September 1990-Present

Appendix V: Cell Wall Polysaccharide/Oligosaccharide/Protocol Requests

Received from September 1990-August 1991 


\title{
THE CENTER FOR PLANT AND MICROBIAL COMPLEX CARBOHYDRATES AT THE UNIVERSITY OF GEORGIA COMPLEX CARBOHYDRATE RESEARCH CENTER
}

\author{
ANNUAL REPORT \\ September 15, 1990-December 31, 1991
}

\section{OVERVIEW}

The Complex Carbohydrate Research Center (CCRC) was established in September 1985. In 1987, the CCRC was awarded a three-agency Plant Science Center grant for the study of the carbohydrates of plants and of microbes that interact with plants. This three-agency Plant Science Center grant has been of the utmost importance to the success of the CCRC and is, indeed, the backbone that holds the CCRC together. During the first four years of funding, the Plant Science Center grant has supported the core of the CCRC, including personnel and the operation and maintenance of equipment. Without this funding, in all likelihood the CCRC would probably collapse.

The Plant Science Center grant funds are used to support basic research in carbohydrate science; training of graduate students, postdoctoral research associates, and visiting scientists; collaborative carbohydrate research projects with other institutions; senvice for carbohydrate analyses to other institutions; and a two week training course for members of the scientific community in the methods used to analyze complex carbohydrates. We are particularly proud of the diversity of the carbohydrate science supported by this grant. The subjects extend from oligosaccharides that protect plants against viruses to oligosaccharides that induce explants to flower, from receptors for oligosaccharides that elicit phytoalexins to oligosaccharides that regulate ion transport across plasma membranes, from the structures of pectic and hemicellulosic polysaccharides to the ability of pathogenesis-related enzymes to release phytoalexin elicitors from fungal cell walls, from the cloning of carbohydrate-degrading enzymes to the cloning of glycanase inhibitors, from the identification of oligosaccharides that kill plant cells to the ctoning of receptors that perceive those oligosaccharides that inhibit root formation and stimulate flower formation, from characterization of bacterial polysaccharides that have useful physical characteristics to characterization of complex carbohydrates involved in Rhizobium symbioses, and from developing analytical methods to purify and characterize carbohydrates to the development of computer methods to reduce the time needed to structurally characterize carbohydrates. This diversity is enabled by the interplay of expertise that is possible in a center environment.

Of the six objectives of the original Plant Science Center proposal, five objectives continue to dominate our goals. The sixth, which was to provide a database for complex carbohydrate structures, is now funded by a separate and independent research grant (Department of Energy grant no. DE-F(09-91ER13970). In this fifth-year proposal, we have described the progress we have made in the five major areas as well as the proposed work for the coming year. In most cases, the proposed work is a continuation of that begun under previous years' funding. The five objectives that we strive to achieve are the following:

1. To carry out basic research in complex carbohydrate science with an emphasis on the carbohydrates of plants and microbes that interact with plants. All of the research projects supported by this grant are collaborative projects or are projects pursued by students supported by this grant. These projects are summarized in sections $A$ and $B$. The publications resulting from this work are listed in Appendices I and II.

2. To assist the larger research community by forming collaborative projects. The ongoing collaborative projects supported by this grant are summarized in section $A$, where previous results and proposed research are described. We are particularty proud of our collaborative 
research projects and, as can be seen in section $A$, we have initialed and continue to work on 15 such projects. Many of these projects are in new, exciting areas of plant biology and carbohydrate science.

3. To train graduate students and postdoctoral research associates. A primary function of the CCRC Plant Science Center is the training of graduate students and postdoctoral research associates. These personnel are trained in the techniques of purification and structural characterization and in the methods for determining biological activity and the mode of action of complex carbohydrates. We emph:asize that these personnel be trained in using the sophisticated equipment necessary to answer the questions of the projects described. In particular, all of our postdoctoral research associates and graduate students have the opportunity to learn to use equipment like NMR spectrometers, high-mass mass spectrometers, GC-MS, LC-NS, GC, and many separation techniques for complex carbohydrates and for enzymes that are used to analyze complex carbohydrates. All of the postdoctoral research associates trained under this grant are involved in the collaborative research projects. The graduate students pursue their own independent research projects concerned either with the structural determination of cell wall polysaccharides or with the characterization and identification of oligosaccharins. Their research projects are summarized in secticn $B$, and these projects underscore the diversity and depth of training that these students receive in the methods for the study of complex carbohydrates. It is a major goal of this center to provide pistdoctoral research associates and graduate students with all the techniques necessary to enabie them once they leave the CCRC to establish their own independent research into the areas of complex carbohydrates with an emphasis on plant science.

4. To offer training couises on the methods to purify and structurally analyze complex carbohydrates. This last year we successfully conducted our second two-week training courses that are described in Appendix III. In this coming year, we intend to hold similar training courses, although under the advice of our Advisory Committee and that of the NIH Resource Center Advisory Committee (that also funds part of the training courses), the courses will be held two to three weeks later than last year so that students from universities around the country can attend the courses. Previously, the dates conflicted with the final exam week of most of the major U.S. universities.

5. To provide complex carbohydrate analytical services to the scientific community. In particular, we offer glycosyl-residue and -linkage composition analyses, NMR analysis, and mass spectrometric analysis. In recent months, we have doubled our efforts to advertise the availability of these services to the scientific community. Our success in this endeavor can be seen in the large number of samples that we are now analyzing. (A summany of analytical services we have performed in the last year is given in Appendix IV.) For the coming year, we propose to continue to advertise our services and to mainiain our record of not turning away any reasonable service request. Analytical service work leads to collaborative research efforis. One fine example of this is the collaborative research effort described in section A (project 10) between William York and John Glushka of thy CCRC and Herman Spaink and colleagues of Leiden University, The Netherlands, in which the final result of a collaborative research project was the complete structural characterization of a Rhizobium nodulation factor.

The funding requested will continue to pay for the salaries of the graduate students, postdoctoral research associates, and technical personnel of the CCRC who perform all of the above-described functions of the Plant Science Center. In adosition, funds are requested to maintain and upgrade the sophistica:ed analytical equipment necessary for the completion of the described research and for the training of personnel in the methods of complex carbohydrate analyses. One new piece of equipment is requested, of which $50 \%$ matching funds are being requested from the University of Georgia. This is for a pholodiode array spectrophotometer detector that will be used for the detection of oligosaccharides and glycopeptides fragmented from cell wall polysaccharides and, more particularly, from cell wall glycoproteins to allow for the sequence structural determination of cell wall glycoproteins. 
The staff and research personnel of the CCRC funded by the Plant Science Center grant continue to strive to make the CCRC the world's foremost research center for the study of complex carbohydrates.

\section{A. COLLABORATIVE PROJECTS OF THE CCRC SPONSORED BY THE PLANT SCIENCE CENTER GRANT}

The CCRC has initiated a number of collaborative projects since the formation of the Plant Sirience Center. The progress made on these projects during the past year, together with proposed research, are described in the following paragraphs.

1. Structural determination of soybean Isoflavones which speclfically Induce Bradyrhlzoblum Japonicum nodD1 but not the nodYABCSUIJ operon. Collaboration with Gary Stacey, Department of Microbiology, University of Tennessee, Knoxville, TN. CCRC investigators: Russell Carison, V. Puvanesarajah (now at ABC Labs, Columbia, MO)

Rhizobia are gram-negative bacteria which form nitrogen-fixing nodules on their host legume plants. The genes in the bacterial symbiont responsible for this process are called nodulation (nod) genes. These genes are activated by flavone molecules from the legume. In addition to the flavones, activation requires the product of one nod gene, nodD. Some rhizobia contain more than a single nodD gene. B. japonicum has two nodD genes. One of these, nodD1, was found to be essential for flavonoid induction of the other nod genes (e.g., nodYABC). In contrast to other rhizobia, the nodD1 gene is also inducible. The isoflavones genistein and daidzein are good inducers of all the $B$. japonicum nod genes, including nodD1. In this collaborative project, it has been found that soybean seeds also excrete compounds that are not inducers of the nodYABCSUIJ genes, but enhance induction of this operon in the presence of a suboptimal genistein concentration. These compounds were purified and their structures determined by NMR, GC-MS, and FAB-MS. They proved to be isoflavone de rivatives and are specific inducers of nodD1 but not the nodYABCSUIJ operon. These isoflavones proved to be malonylglucosyl derivatives of genistein (6"-malonylgenistin), daidzein (6"-rnalonyldaidzin) and glycitein $\left(6^{*}\right.$-malonylglycitin). The following manuscript describing this work has been submitted for publication:

(3. Smit, V. Puvanesarajah, R.W. Carlson, V.M. Barbour, and G. Stacey. 1991. Braldyrhizobium japonicum nodD1 can be specifically induced by soybean flavonoids which do not induce the nodYABCSUIJ operon. J. Biol. Chem., submitted.

2. Structural analysis of the Ilpopolysaccharides (LPSs) from symblotle mutants of Briadyrhlzoblum Japonlcum. Collaboration with Gary Stacey, Department of Microbiology, University of Tennessee, Knoxville, TN. CCRC investigators: Russell W. Carlson, U. Ramadas Bhat, and S.K. Bhagyalakshmi.

A T 5-containing symbiotic mulant of B. japonicum 61A101C, JS314, was found to defective in that it failed to nodulate several soybean varieties, while on a few varieties nodule-like structures were formed. These nodule-like structures were devoid of bacteria, possessed cential vascular tissue and exhib:ted localized cell death of epidermal cells. Isolation and characterization of the cell-surface polysaccharides from the parent and mutant strains revealiad that the mutant produced normal extracellular polysaccharides (EPSs) in somewhat incre sed amounts. Analysis of the LPSs showed that the mutant produced a defective LPS in that the $O$-specific polysaccharide was missing. These results have iecently been publis hed:

G. Stacey, J.-S. So, L.E. Roth, S.K. Bhagyalakshmi, and R.W. Carison. 1991. A lipopoly'saccharide mutant of Bradyrhizobium japonicum that uncouples plant from bacterial differentiation. Mol. Plant-Microbe Interac. 4:332-340. 
Further structural analysis of these LPSs has been carried out by mild acid hydrolysis, isolation of the core oligosaccharides by P2 gel filtration and Dionex HPLC, NMR, FAB-MS, and methylation (GC-MS) analysis. Two principal core oligosaccharides were found in the mulant: a trisaccharide consisting of a mannosyl residue $\alpha$-linked to $\mathrm{C} 4$ of a glucosyl residue that is in tum $\alpha$-linked to $C 5$ of KDO, and a disaccharide consisting of a 4-O-methylmannosyl residue $\alpha$-linked to C5 of KDO. The parent strain produces only the trisaccharide and the $O$ chain polysaccharide on mild acid hydrolysis. The O-chain polysaccharide contains the 4-O methylmannosyl residue. These results indicate that the mutant is defective in an LPS synthesis step after the addition of 4-O-methylmannose to the LPS. A manuscript is in preparation describing the structures of these oligosaccharides.

3. Structural characterization of Ilpoollgosaccharldes from Bradyrhlzoblum Japonlcum that are requlred for the speclflc nodulation of soybean. Collaboration with Gary Stacey, Department of Microbiology, University of Tennessee, Knoxville, TN; and Herman Spaink, Department of Plant Molecular Biology, University of Leiden, Leiden, The Netherlands.. CCRC investigators: Russell W. Carlson and U. Ramadas Bhat.

During the past year Denariés group in France reported the structure of compound produced the nodABCHPQ gene products from $R$. meliloti, the symbiont of alfalfa. This compound (called a nodulation factor, NodRm1) proved to be a chitin tetrasaccharide which is derivatized by a doubly unsaturated fatty acyl group at the non-reducing terminal glucosamine residue and a sulfate group at $\mathrm{C} 6$ of the reduction $\mathrm{N}$-acetylglucosamine residue. Apparently the genes involved in determining host-specificity, namely nodP and nod $Q$, are involved in the sulfation of this oligosaccharide (shown by Sharon Long of Stanford). Other work by $H$. Spaink and colleagues in Leiden has shown that similar tactors are produced by $R$. leguminosarum biovar viciae strains. However, the factor which is specific for biovar viciae varies in the type of fatty acyl group present and by the fact that it is not sulfated. The $B$. japonicum-soybean system is of interest because (a) soybean has importance as a crop plant, (b) soybeans form a different type of nodule (determinant rather than indeterminate) than do pea, vetch or alfalfa, (c) the nod genes of B. japonicum are located on the chromosome instead of on a plasmid and appear to be regulated in a slightly different manner than those of $R$. meliloti and biovar viciae, and (d) the host range of $B$. japonicum is greater and, thus, there are a larger number of nod genes that determine host specificity.

Thus far, several of the B. japonicum nodulation factors, $\mathrm{NadBj}$, have been isolated and partially characterized. Biological assays have shown that they are potent stimulators of root hair curling, formation of thick short roots, and cortical cell division in soybean. Structural investigations have involved NMR, FAB-MS, mild methanolysis and GC-MS, and methylation and GC-MS. The results thus far indicated that the NodBj factors are chitin pentasaccharides that vary in the fatty acyl residue at the non-reducing terminal glucosamine residue, can be acetylated at $\mathrm{C} 6$ of this same residue, and contain an as yet unidentified substituent on the reducing $\mathrm{N}$-acetylglucosamine. Our present focus is to determine the structure of this unidentified substituent and then to determine the structures of modified $\mathrm{NodBj}$ factors from $\mathrm{Bj}$ mutants that are affected in their host range, i.e. they nodulate one host normally but are defective in the nodulation of a second host.

4. Siructural characterlzation of the LPSs from R. Leguminosarum blovar phaseoll, the symblont of bean. Collaboration with Dale Noel, Department of Biology, Marquette University, Milwaukee, WI. CCRC investigators: Russell W. Carlson and U. Ramadas Bhat.

Or. Noel was the first investigator to discover that certain symbiotic mutants defective in nodule development are also defective in their LPS structures. Working with Dr. Noel, we confirmed that these mutants contain LPSs that lack their Ochain polysaccharide. Since that rime, investigators from several other laboratories have coniirmed the importance of a complete LPS in the symbiosis between every Rhizobium-legume system examined. Structural analysis of the LPS from several of biovar phaseoli mutants has shown that these 
LPSs contain defective core oligosaccharides. The structures of these core oligosaccharides as originally reported were not completely correct as determined by further analysis. A manuscript describing the correct structures is in press:

U.R. Bhat, S.K. Bhagyalakshmi, and R.W. Carlson. 1991. Re-examination of the structures of the lipopolysaccharide core oligosaccharides from Rhizobium leguminosanm biovar phaseoli. Carbohydr. Res., in press.

Recently Dr. Noel has discovered, using monoclonal antibodies, that LPS structural epitope changes occur during the differentiation of bacteria to nitrogen-fixing bacteroids within the nodule. Furthermore, he has discovered that one of these epitope changes depends on the presence of the symbiotic plasmid and on conditions that induce nod genes. These epitope changes can be reproduced in part by growing the bacteria at low $\mathrm{pH}(5.0)$. Analysis by PAGE immunoblots has shown that these epitope changes occur in the O-chain portion of the LPS. We have been characterizing the structural basis for these changes. The LPSs from bacteria grown at normal and low pH have been isolated and their O-chain polysaccharides purified by mild acid hydrolysis and gel filtration chromatography. Composition analysis has revealed that the major change when going from normal to low $\mathrm{pH}$ is the disappearance of 2,3,4-tri-O-methylfucose and the appearance of 2,3 di-Omethylfucose. A manuscript describing these results is being submitted for publication:

U.R. Bhat and R.W. Carison. 1991. Chemical characterization of pH-dependent structural epitopes of lipopolysaccharides from Rhizobium leguminosarum biovar phaseoli. J. Bacteriol., submitted.

Further work is in progress to determine the complete structure of the biovar phaseoli O-chain.

5. Characterlzatlon of bacterold-speciflc LPS epltopes In R. leguminosarum blovar v/clae. Collaboration with Nick Brewin, John Innes Research Institute, Norwich, UK. CCRC investigators: Russell W. Carlson and U. Ramadas Bhat.

Dr. Brewin was the first investigator to report that the LPS undergoes subtle structural changes during symbiotic infection as detected by using monoctonal antibodies. These structural changes occur in the O-chain polysaccharide of the LPS. Drs. Carlson and Bhat are undertaking the structural analysis of these epitope changes. This project is similar to that described for Dr. Noel, and, in fact, Dr. Brewin and Dr. Noel are also collaborating on the biology of the biovar phaseolibean symbiosis. The $R$. leguminosarum biovar viciae-pea symbiotic system useo by Dr. Brewin is different from the biovar phaseoli-bean system in that the former forms indeterminate nodules while the latter forms determinant nodules. In addition the role of the LPS in these two systems may be different, since for determinant nodules the LPS is required for infection thread development while in indeterminate nodules the LPS is required for the releass of bacteria into the root cortical cells and does not appear to be raquired for infection thread development. We had attempted to grow bacteria under conditions that are known to produce the same epitope changes that occur in the nodule. However, when the resulting L.PSs were checked using appropriate monoclonal antihodies, the desired epitopes had not teen produced. During the past several months, Dr. Brewin's laboratory has successfully grown larger batches of bacteria that contain LPSs with the bacteroid-specific epitopes. The structures of these LPSS are being investigated. Dr. Brewin also has mutants that are unable to produce the bacteroid-specific LPS. A number of these mutants form defective nodules. The structures of the LPSs from these mutants will also be investigated.

6. Analysis of the surface polysaccharldes of Rhlzoblum melllotl mutants whose Ilpopolysaccharldes and extracellular polysaccharldes can have the same function In symblosls. Collaboration with Adam Kondorosi and Peter Putnoky, Institute of Genetics, 
Biological Research Center, Hungarian Academy of Sciences, Szeged, Hungary. CCRC investigators: Russell W. Carlson and Brad Reuhs.

Rhizobium meliloti strains are symbionts of alfalfa. The EPSs from $R$. meliloti are required in order to form an effective symbiosis. R. meliloti EPS mutants form empty nodules. Recently, another type of $R$. meliloti strain was discovered in which EPS mutants still form effective nitrogen-fixing nodules. However, mutants of these EPS strains were discovered by Dr. Kondorosi (as well as Dr. Signer at MIT) that have the same phenotype as the usual EPS. strains. Their data suggest that these mutants are defective in the synthesis of their LPSs. We have been characterizing the surface polysaccharides of an EPS- parent and a putative LPS defective (and symbiotically defective) mutant. The LPSs from both the parent and the mutant strains were extracted using the phenol/water extraction procedure. The material extracted into the water phase was further purified by gel filtration chromatography. Analysis of the water-extracted material indicated that it was very rich in KDO from the parent strain and from the mutant strain. Gel filtration fractions were assayed for both KDO and for LPS by PAGE analysis of each fraction. These results showed that the LPS could be separated from a 3-deoxy-D-manno-2-octulosonic acid(KDO)-rich peak in the case of the parent strain. In the case of the mutant, the LPS was also separated from the KDO-containing polysaccharide, however, the KDO-containing polysaccharide was very heterogeneous in size and was distributed throughout a large portion of the gel filtration column fractions. PAGE analysis of the LPS fractions from both the parent and the mutant strains gave identical banding patterns.

These results indicate that there is a KDO-containing polysaccharide in these strains that is defective in the mutant, and that the defect may not affect the L.PS. In order to confirm the defect in this mutant, both the KDO-containing polysacctaride and the LPSs from the parent arid mutant are being purified and their structures characterized. Previous reports have shown that $R$. meliloti strains can produce two different EPSs which can function in symbiosis. It is possible that a third acidic polysaccharide is produced that can also substitute for either of these previous two EPSs in symbiotic infection.

7. Characterization of a polysaccharide produced by certain Bradyrhlzoblum laponlcum stralns within soybean nodules. Collaboration with John Streeter, Department of Agronomy, Ohio State University, Wooster, OH. CCRC investigator: Russell W. Carlson.

Bradyrhizobium japonicum can be divided into two groups based on the type of EPS they produce in culture. Group I produces EPS containing glucose, mannose galacturonic acid, galactose and 4-O-methylgalactose. Group II produces EPS containing mamnose and 4-O methylglucuronic acid. However, neither of these EPSs appears to be required since EPS. mutants of these strains can form effective nitrogen-fixing nodules. The lack of requirement for EPS in symbiotic infection is true for those hosts that form determinant nodules of which soybean is one example. Dr. Streeter discovered that certain B. japonicum strains produce nodules that contain a very viscous polysaccharide. Strains that produce this polysaccharide, independent of the variety of soybean host, were found exclusively in serogroups 123 and 31. Strains in these serogroups represent EPS Group I and II, respectively, and are also known for their dominance in midwestern and southeastern soils. This polysaccharide was purified by ethanol precipitation, CTAB precipitation, and DEAE ion-exchange chromatography. Analysis of this polysaccharide from nodules produced by 123 strains showed that it consists of mamnose, galactose, and 2-Omethylglucuronic acid.

This same nodule polysaccharide was found in nodules from five different soybean cultivars nodulated by serogroup 123 strains. Thus, serogroup 123 strains, EF'S Group I, produce a polysaccharide in the nodule that is entirely different from the EPS produced in culture. Serogroup 31 produces a nodule polysaccharide that contains rhamnose and 4.0 methylglucuronic acid in an identical ratio to that found in the EPS it produces in culture. Thus, this Group II strain produces a nodule polysaccharide that may be very similar to the EPS it produces in culture. In a survey of strains that produce these nodule polysaccharides, 
onty those strains in serogroups 123 and 31 were found to produce nodule polysaccharide ( $70 \%$ of these strains). Nodule polysaccharide was not found in nodules produced by other seragruups. It is hypothesized that this nodule polysaccharide may be important in the persisionce of serogroups 123 and 31 in soils. A manuscript describing this work has been submitted to the Proceedings of the National Academy of Sciences.

8. Structural analysis of a streptococcal adhesin polysaccharlde receptor. Collaboration with Frederick J. Cassels, Department of Gastroenterology, Walter Reed Army Institute of Research, Washington, DC. CCRC investigators: Russell W. Carlson, Herman van Halbeek and John Glushka.

Dental plaques are formed by the adherence of microbes to one another and to the tooth. Two bacterial partners in such an interaction are Streptococcus sangui $\mathrm{HI}$ and Capnocytophaga ochracea. Recently we have determined the structure of the repeating unit of the Streptococcus sangui $H 1$ polysaccharide that is involved in this interaction, $\alpha-L-R h a p-$

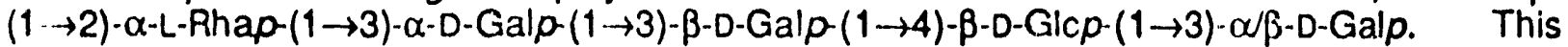
work was recently published:

F.J. Cassels, H.M. Fales, J. London, R.Vi. Carlson, and H. van Halbeek. 1990. Structure of a streptococcal adhesion carbohydrate receptor. J. Biol. Chem. 265:14127-14135.

This repeating unit was obtained from the polysaccharide by hydrolysis in $48 \%$ HF which supposedly hydrolyzed the phosphate diester that bridges the repeating units. We have been attempting to characterize the location of the phosphate residue in the polysaccharide. Methylation and GC-MS analysis have shown that the reducing galactosyl residue in the isolated repeating unit is actually a galactofuranose residue in the polysaccharide and that the terminal hamnosyl residue is a 3 -linked rhamnosyl residue. Also, methylation analysis of the polysaccharide could only account for two of the three galactosyl residues, indicating that the phosphate group was present on the $\alpha$ - or $\beta$-3-linked galactopyranose residue. Analysis by NMR $\left({ }^{13} \mathrm{C}\right.$ and $\left.{ }^{1} \mathrm{H}\right)$ showed that the galactofuranose residue was $\beta$-linked. Proton assignments were made by COSY, HMOC, and HOHAHA experiments, and the sequence of glycosyl residues determined by a ROESY experiment. 31P-NMR at pH 7.0 and 9.5 showed that the phosphate residue was present as a diester in that the shift in $\mathrm{pH}$ did not resuit in a change in the phosphate chemical shift. Proton-phosphorus 2-D NMR of the polysaccharide indicates that the phosphate is esterified to C6 of the $\alpha-3$-galactosyl residue and also to another substituent previously not observed. Present evidence indicates that this substituent is glycerol. Further work is in progress to complete the structural analysis of this polysaccharide.

9. Conformational studles of xyloglucan. The role of the fucosylated side chain in surface-speclflc cellulose-xyloglucan Interactlons. Collaboration with Samuel Levy and Andrew Staehelin, University of Colorado, Boulder, CO. CCRC investigators: William S. York, Bernd Meyer, and Rainer Stuike-Prill.

Theoretical calculations were performed (for the most part at the CCRC) using the GEGOP software developed by Meyer and Stuike-Prill at the CCRC to simulate the molecular conforinations of xyloglucans. The conformational energies of model oligosaccharides consisting of from 2 (cellobiose) to 17 residues were calculated. Low energy (i.e., highiy populated) conformations were proposed for these model compounds, and Metropolis Monte Carto simulations were performed in order to evaluate their dynamic properties. The results indicated that the preferred position of the fucosylated side chain of xyloglucans depends on the backbone conformation. Two xyloglucan backbone conformations were studied, a "fiat" conformation which putatively binds to cellulose by virtue of a complementary surface, and a lower energy "twisted" conformation, presumed to be the dominant conformation in solution. The position of the fucosylated side chain of thie model xyloglucans was influenced by the conformation of the backbone, and vice verse. This result, along with topological 
considerations, allowed us to propose a model for nucleation of xyloglucan-cellulose binding in which a specific surface of the xyloglucan (which we reler to as the H4s face) attaches to the cellulose microfibril, while the side chains fold to the opposite face. The self-association of fucosylated xyloglucan molecules is presumably minimized because of the proposed tendency of the fucosylated side chain to fold onto the $\mathrm{H}_{4}$ s face when the polymer is in solution and to fold onto the opposite (H1s) face only in locally flattened areas. Consideration of the entropy and enthalpy of binding would explain how binding of such a locally flattened xyloglucan molecule to a cellulose crystalite could proceed in a cooperative manner, while the xyloglucan would not form stable self-associations. This result provides a theoretical basis to understand the process of self-assembly of cellulose synthesized at the plasmalemma and xyloglucan synthesized in the Golgi. The work has been appeared in the following publications:

S. Levy, W. S. York, R. Stuike-Prill, B. Meyer, and L.A. Staehelin. 1991. Simulations of the static and dynamic molecular conformations of xyloglucan. The role of the fucosylated sidechain in surface-specific sidechain folding. The Plant J. for Cell \& Mol. Biol., in press.

R. Stuike-Prill and B. Mey'er. 1990. A new force-field program for the calculation of glycopeptides and its application to a heptacosapeptide-decasaccharide of immunoglobulin- $G_{1}$ : inportance of $(1-6)$-glycosidic linkages in carbohydrate-peptide interactions. Eur. J. Biochem. 194:903-919.

10. The structure of an acylated glucosamine ollgosaccharlde slgnal molecule (nod factor) involved in the symblosis of Rhizobium leguminosarum blovar viclae with its host Vicla satlva. Collaboration with Herman Spaink, Anton A. N. van Brussel, Teun Tak, and Ben J. J. Lugtenberg, Department of Molecular Biology, Leiden University, Leiden, The Netherlands; Douglas M. Sheeley and Vernon Reinhold, Department of Nutrition, Harvard School of Public Health, Boston, MA; and Eugene P. Kennedy, Department of Biological Chemistry and Molecular Pharmacology, Harvard Medical School, Boston, MA. CCRC investigators: John Glushka and William S. York.

The host specificity of the symbiotic relationship between bacteria of the genus Rhizobium and leguminous plants is determined in part by bacterial genes called nod genes which have been shown by several laboratories to be required for the production of biologically active acylated glucosamine oligosaccharide signals. The nodf and nodE gene products of Rhizobium leguminosarum biovar viciae were shown in the study described here to be involved in the production of a novel, highly unsaturated lipid substituent on the oligosaccharide signal molecule. The presence of this novel lipid substituent appears to be required in order for the lipooligosaccharide to induce nodule meristems in vitro on the host plant vicia sativa.

Determining the structure of the signal oligosaccharide proved to be quite challenging due to the unusual nature of the lipid moiety. Two-dimensional NMR analysis performed at the CCRC allowed the structure of the lipid moiety to be unambiguously determined. Six proton resonances $(\delta 5.88$ to 7.0$)$ indicated the presence of an $\alpha, \beta$-unsaturated carbonyl system. The connectivity of these resonances was confirmed by DQF-COSY and HOHAHA spectroscopy, and the configuration of the double bonds was assigned by examination of $3 \mathrm{~J}$ homonuclear coupling constants and by analysis of pertinent ${ }^{13} \mathrm{C}$ chemical shifts. The positions of the double bonds were determined by tracing the connectivities of adjacent protons and by integration of proton signals. The complete structure of the biologically active lipooligosaccharide was determined using a combination of two-dimensional NMR analysis (described in part above) and FAB-MS. The results of this work have been submitted for publication:

H.P. Spaink, D.M. Sheeley, A.A.N. van Brussel, J. Glushka, W.S. York, T. Tak, O. Geiger, E.P. Kennedy, V.N. Reinhold, and B.J.J. Lugtenberg. 1991. A novel, highly unsaturated, fatty acid moiety of lipoologosaccharide signal molecules determines host specificity of Rhizobium leguminosarum biovar viciae. Nature, submitted. 
11. Investlgating membrane responses Induced by ollgogalacturonldes in cultured cells. Collaboration with Jean Guern, CNRS Plant Science Institute, Gif sur Yvette, France. CCRC investigators: Peter Albersheim, Alan Darvill, Malcolm O'Neill, Mark Spiro.

We have shown that treatment of suspension-cultured tobacco cells with a highly purified dodecagalacturonide and a tridecagalacturonide induces $\mathrm{K}^{+}$efflux, $\mathrm{Ca}^{2+}$ influx, acidification of the cytoplasm, and membrane depolarization. The binding and uplake of bioactive oligogalacturonides by tobacco cells is now being studied. A tritiated dodecagalacturonidegalactitol derivative was prepared. The tridecagalacturonide was reduced with $\mathrm{NaB}^{3} \mathrm{H}_{4}$ in ammonia to convert the reducing galacturonic acid to galactonic acid. The galactonic acid was lactonized in the presence of acetic acid and then reduced with $\mathrm{NaBH}_{4}$ in water 10 give galactitol.

FAB-MS of the product showed the presence of the dodecagalacturonide-galactitol $3 \mathrm{H}$ reduced 13-mer) and a small amount of undecagalacturonide-galaciitol $3 \mathrm{H}$-reduced 12-mer). The material had approximately $20,000 \mathrm{dpm} / \mu \mathrm{g}$. This material was biologically active as it also induced $\mathrm{K}+$ efflux in tobacco cells. Portions $(100,000 \mathrm{dpm})$ of the ${ }^{3} \mathrm{H}$-reduced material were added to suspension-cultured tobacco cells $(200 \mathrm{mg})$ and incubated separately for 2, 20, 50 , and $180 \mathrm{~min}$. At each time point three separate fractions were prepared. Fraction 1 contained cells that were removed by centrifugation and washed with fresh media which was pooled with the initial growth medium. The combined media were dialyzed (1,000 MW) against water. Fraction 2 contained the washed cells that had been extracted with $0.5 \mathrm{M} \mathrm{NaCl}$ and the extract dialyzed $(1,000 \mathrm{MW})$ against water. Fraction 3 contained the residue remaining after salt extraction of the cells.

The distribution of the ${ }^{3} \mathrm{H}$ after 2 min incubation was fraction 1,73\%, fraction $2,22 \%$, and fraction $3,5 \%$. There was a similar ${ }^{3} \mathrm{H}$ distribution in the corresponding fractions isolated from cells incubated for 20,50 , and $180 \mathrm{~min}$. The distribution of the ${ }^{3} \mathrm{H}$-labeled oligogalacturonides was determined by HPAE-PAD in combination with liquid scintillation counting. Prior to HPAE-PAD analysis, fraction 3 (the cell residue) was extracted with $\mathrm{M} \mathrm{KOH}$ containing $\mathrm{NaBH}_{4}$ and the soluble material analyzed.

${ }^{3} \mathrm{H}$-labeled oligogalacturonides (DPS $=7-10$ ) were detected in fraction 1 between 2 and 50 min. After $180 \mathrm{~min}{ }^{3} \mathrm{H}$-labeled oligogalacturonides (DPs $=5-7$ ) were detected in fraction 1. The material released by salt extraction (fraction 2) contained only ${ }^{3} \mathrm{H}$-labeled undecagalacturonide-galactitol (reduced 12-mer) and dodecagalacturonide-galactitol (reduced 13-mer). However, between 50 and $180 \mathrm{~min}$ the $3 \mathrm{H}$ label began to appear in smaller fragments (DPS $=9-13$ ). No ${ }^{3} \mathrm{H}$-labeled oligogalacturonides were detected in fraction 3.

These preliminary results suggest that a proportion $(20 \%)$ of the ${ }^{3} \mathrm{H}$-tridecagalacturonide was rapidly bound by the tobacco cells and was degraded slowly to smaller fragments (DPs = 913). Surprisingly, the material that did not bind (fraction 1 ) was rapidly degraded to oligomers with DPs of 7 to 10 and over a longer period of time $(180 \mathrm{~min})$ is degraded to sinaller fragments (DPs $=5-7$ ). However, no oligomers with DP $<5$ were detected. However, we cannot at this time discount the possibility that oligogalacturonide-galactitol derivatives cannot be completely degraded by enzymes in the cell culture medium. Cold, reduced oligogalacturonides will be prepared and their susceptibility to plant and fungal endopolygalacturonases determined. Further studies designed to determine if oligogalacturonide binding to tobacco cells is specific and reversible will require the preparation of a ${ }^{3} \mathrm{H}$-labeled 8 -mer, 13 -mer, and 17 -mer. This work is now in progress. This work on binding and uptake of oligogalacturonides may lead to a better understanding of the initial recognition events that occur between biologically active oligogalacturonides and cultured plant cells. 
In addition, Prolessor Guern and colleagues are also investigating the effect on cultured cells and possibly protoplasts of oligogalacturonides in the presence of fusicoccin and auxin. These studies are aimed at determining the interactions of thes 3 molecules on rapid membrane responses.

12. The polygalacturonase inhlbltor proteln. Collaboration with Felice Cervone and Giulia De Lorenza, University of Rome, Ilaly; and with Nicole Behamu, Laval University, Quebec, Canada. CCRC investigators: Peter Albersheim, Alan Danill, Cant Bergmann, Yuki lio.

Endo $\alpha-1,4-D$-polygalacturonase (EC 3.2.1.15) are important pathogenicity factors of fungi (Cooper, 1984, In Plant Disease: Infection, Damage and Loss, Blackwell Sinientific Publications, pp. 13-27; Hahn et al., 1989, In Plant-Microbe Interactions, Vol. 3, McGraw Hill, op. 131-181). EPGs are the first detectable enzymes secreted by phytopathogenic furigi grown in vitro on plant cell walls (Jones et al., 1972, Physiol. Plant Pathol. 2:153-166), and catalyze the fragmentat. un and solubilization of plant cell wall homo- $\alpha-1,4-D$-galacturcnans. Pre-treatment of piant cell walls with EPG appears to lacilitate the ability of other fungalsecreted piant cell wall-degrading enzymes to attack their substrates (Karr et al., 1970, Plant Physiol. 46:69-80). In this way, EPGs assist in the colonization of the plant tissue and provide nourishrnent for the fungus. On the other hand, endopulygalacturonases are potential avirulence factors, as they can activate plant defense responses such as necrosis, lignification, synthesis of proteinase inhibitors, and synthesis of phytoalexins by generating oligogalacturonide elicitors from the plant cell wall homogalacturonans (Hahn et al., 1989, in Plant-Microde Interactions, Vol. 3, McGraw Hill, pp. \$31-181; Cenone et al., 1987, Plant Physiol 85:631-637; Robertsen, 1986, Physiol. Mol. Plant Pathol. 28:137-148; WalkerSimmons et al., 1984, Plant Physiol. 76:787-790; Lee et al., 1981, Plant Physiol 67:633-639; Jin and West, 1984, Plant Physiol 74:989-992). Ali dicots thus far examined contain a cell wall-associated protein (PGIP) that inhibits fungal endopolygalacturonases (reviewed in Hahn et al., 1989, In Plant-Microbe Intcractions, Vol. 3, McGraw Hill, pp. 131-181). PGIP, which is present in different parts of Phaseolus vulgaris L. (Salvi et al., 1990, Plant Physiol 136.513. 518), inhibits fungal endopolygalacturonases but not plant and bacterial endopolygalacturonases or other microt al pectic enzymes (Cenone et al., 1990, Phytochem. 29:447-449). The inhibition by PGIP of the ability of fungal endopolygalacturonases to hydrolyze polygalacturonic acid results, in vitro, in the prolonged existence in the digestion mixture of oligogalacturonides active in eliciting phytoalexins and other defense responses (Cervone et al., 1989, Plant Physiol 90:542-548). Thus, it has been hypothesized that PGIP plays a role in plant resistance to fungal pathogens by lavouring the formation of oligogalacturonides of the proper size to elicit plant defense responses.

An important question to answer is whether the amount of PGIP is increased (induced) in cells that surround an attempted infection site. Preliminary results indicate PGIP is induced, but these results are difficult to evaluate because it is virtually impossible to determine by clasuical extraction methods and assay procedures the proportion of infected plant tissue that has responded to an attempted infection. For example, if a large amount of PGIP is formed by a relatively small number of cells reacting to the pathogen and most cells in the tissue extracted had no increase in. PGIP content, determination of lolal tissue PGIP content would seriously under-estimate the effective PGIP concentration around the sile of infection.

A major objective of this project is the cloning of the gene coding for PGIP for use in in situ hybridization studies. The expression of FGIP mRNA in d:ferent parts of Phaseolus and upon infection of the plant with phytopathogenic fungi will be studied. Toward this end, the $N$ terninus and several internal tryptic peptides of PGIP purified from P. vulgaris $\mathrm{Cv}$. Pinto were sequianced by automated Edman degradation. The amino acid sequence of the $\mathrm{N}$-terminus and of one of the tryptic peptides was used to design redundant oligonucleotides that were successfully utilized as primers in a polymerase chain reaction (PCR) with total DNA of $P$. vulgaris as a template. A DNA band of 758 base pairs (a specific PCR amplification product of

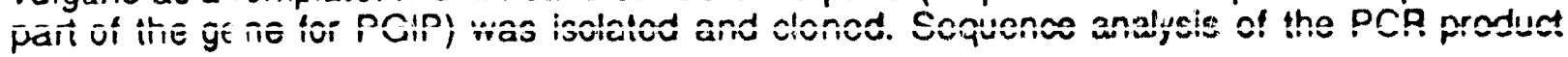


demonstrated that it consisted of an uninterrupted reading lrame coding for a total of 252 amino acids. The deduced amino acid sequence included the sequences of the two peptides used to design the primers for the PCR as well as the sequences of three other peptides obtained by trypsin cijustion of PGIP. By using the 758-bp DNA as a hybridization probe, a larnbda clone containing the PGIP gene was isolated from a genoinic library of $P$. vulgaris CV. Saxa. The coding and immediate flanking regions of the PGIP gene, contained on a subcloned $3.3 \mathrm{~kb}$ Sall-Sall DNA fragment, were sequenced. A single, continuous ORF of $1026 \mathrm{nt}$ (342 aa) was present in the canomic clone. The nuclestide and deduced amino acid sequences of the PGIP gene showed no significant similarily with any known databank sequence. Southern blot analysis of $P$. vulgaris EcoRl-digested total DNA, carried out at high stringency using the PCR-generated DNA fragment as a probe, suggested that the PGIP gene is present as a small multigene family in the bean genome. Two of the PGIP jenes were estimated to be present in three to four copies per haploid genome. Northern blotting analysis of poly $(A)+$ RNAs, isolated from various tissues of bean seedlings or from suspension-cultured bean cells, were also performed using the cloned PCR-generated DNA as a probe. A $1.2 \mathrm{~kb}$ transcript was detected in suzpension-cultured cells and, to a lesser extent, in leaves, hypocotyls, and flowers. A cDNA clone containing part of the coding region for the PGIP (from aa 118 to the poly(A) tail) was isolated from a $\lambda \mathrm{g} t 11$ cDNA library prepared from poly-(A)+ RNA isolated from suspension-cultured cells of $P$. vulgaris Cv. Pinto. The nucleotide and deduced amino acid sequences of the PGIP genes from the two different cultivars shared $96.4 \%$ and $97.4 \%$ identity, respectively. Future experiments will include attempts to express PGIP in both plants and bacteria. Over-expression of PGIP in transgenic plants could allow the determination of whether enhanced levels of PGIP increase the resisiance of the piants to pathogens. Expression of PGIP in E. coli would allow production of a deglycosylited form of PGIP to be used for both structural and functional studies.

Wo have succeeded in generating polyclonal antibodies to a synthetic peptide, designed from the N-terminal sequences of PGIP, which had been covalently attached Ic KLH (keyhole limpet hemocyanin) as a carrier. Following purification of the ser:m, the antibody preparation reacted against a single band (shown to run with the same ir as purified PGIP) in Western blots of bean tissues, and did not react to any proteins in Western blots of fungal extracts. This antibody preparation was used in conjunction with gold labellind secondary antibodies to probe leaf tissue of $P$. vulgaris which was either uninfected or infected with Colletotrichum lindemuthianum. Results indicated that, in comparison to uninfected tissue, the amount of PGIP in infected tissue is approximately ten times greater in those cells immediately surrounding the infection site, with little increase in PGIP content in cells further away from the infection site. This work is being pursued with fluorescently labelled secondary antibodies in order to obtain a more precise picture of the extent of PGIP induction in the tissue. We will soon begin time course studies, using both susceptible and resistant race cultivar combinations, to study the possible correlation of race-cultivar susceptibility with the timing of PGIP induction. Through the use of double labelling experiments (using fluorescently labelled secondary antibodies) designed to localize both PGIP and the mRNA coding for PGIP, we hope to be able to determine the level of control of the increase in PGIP during infection.

A number of results in our labs have led us to hypothesizo that the PGIP-EPG complex functions as a receptor-agonist pair which can trigger hypersensitive necrosis, a widely observed defense response of plants. We are now investigating the receptor-agonist hypothesis by determining if EPG-induced/ ant cell death occurs independently of the ability of this enzyme to hydrolyze pectic polymers. Toward this goal, we have generated and sequenced tryptic peptides of Fusarium moniliforme EPG and, as we have done with PGIP, have used the corresponding oligonucleotides and PCR to clone the Fusarium moniliform: EPG. We have also taken advantage of recently published sequences of Aspergillus niger EPG to design oligonucleotides used to generate PCR products using the CDNA oi $A$. niger as a template. These PCR products, containing slightly modified sequences prior to and following the start and stop codons of the mature EPG, are being inserted into expression vectors and used to produce EPG in $E$. coli. Once we have obtained enzymatically active 
forms of EPG in this manner, we wili then generate, by site-directed mutagenesis, forms of EPG that are not enzyrnatically active. If all enzymatically inactive forms of EPG fail to produce necrosis in plant tissues, this will be taken as evidence that it is the oligogalacturonide products of this enzyme that initiate necrosis of plant tissues. However, if unzymatically inactive forms of EPG still induce necrosis, a new function for this protein will have Deen indicated. Furthermore, if EPG mutants can be oblained that are enzymatically active, are no longer inhibited by PGIP, and do not induce necrosis, evidence will have been obtained that PGIP binding is an important part of the necrosis mechanism.

Partial funding for this collaborative work is also obtained from Department of Energy grant number DE-FG09-85ER13425, The Structures and Functions of Oligosaccharins.

13. Characterization of the self-incompatiblilty glycoprotelns from Petunla hybrlda. Cullaboration with Wim Broothaerts, Katholieke Universitait, Leuven, Beigium. CCRC investigators: Peter Albersheim, Alan Darvill, and Roberta Merkle.

Self-incompatibility is the mechanism flowering plants use to prevent self-pollination. At least three glycoproteins $\left(S_{1}, S_{2}, S_{3}\right)$ are involved in the recognition process employed for selfincompatibility in Pelunia hybrida. Dr. Broothaerts has metabolically radiolabeled these glycoproteins with the precursor monosaccharides [3H]mannose, $\beta \mathrm{H}] g a l a c t o s e$, and $\left.{ }^{3} \mathrm{H}\right]$ glucosamine. Dr. Merkle has used methods developed for oligosaccharide separation and structural analysis of radiolabeled animal cell glycoproteins for the analysis of these plant glycoproteins. Our studies involving serial lectin affinity chromatography and composition analysis have indicated that the three glycoproteins have different complements of oligosaccharide structures. We are continuing these analyses on the glycoproteins obtained from additional labeling experiments in order to show that the structural characteristics are similar from one sample to another and to confirm that the complement of structures is indeed unique to eacil of the $S$ glycoproteins. We are using the atrove methods combined with other techniques such as sequential exoglycosidase treatments and methylation analysis to turther define the structural characteristics of the oligosaccharides of the different glycoproteins. We have also separated a fourth, unique incompatibility glycoprotein, $S_{b}$, from $S_{2}$ and have begun analysis of its oligosaccharides. Dr. Broothaerts will visit the CCRC for six months beginning in October 1991 to continue the work on this project under a grant funded by the Belgian government.

14. Investlgation of the cell wall polysaccharlde structures of Arabldopsis thallana. Collaboration with Chris Somerville, MSU-DOE Plant Research Laboratory, Michigan State University. E. Lansing, MI. CCRC investigators: Alan Danvill, Peter Albersheim, Bernd Mülier, and Andrew Whitcombe.

The aim of this newly established project is the investigation of the polysaccharide structures of cell walls from Arabidopsis thaliana wild type and comparison to cell walls from mutants lacking certain sugar components. This project will be achieved by analyzing polysaccharides from plant tissues as well as suspension cultures from wild type and mutant plants. Altered cell wall polysaccharide structures found in mutants inay provide new information about structural features of cell wall polysaccharides like RG-I, RG-II, and xyloglican and may provide important information about the role of polysaccharide structure in cell wall structure and function.

Arabidopsis thaliana is a widely used plant in biochemistry and plant molecular biology. Its small size and its short generation time are just two parameters which make it an ideal model for the study of biochemical processes. These studies are facilitated by easity obtaining and scrzening mutants which have been described concerning a broad variety of melabolic processes [Meyerowiz (1989) Cell 56:263-269]. Its rather small genome makes it an ideal plant for genetic studies. Recently a fucose-deficient mutant has been oblained by Somerville 
and coworkers, a mutant that should show alterations in the structure of the cell wall polysaccharides that contain fucose, e.g., RG-I, RG-II, and xyloglucan.

There have been no reports about the cell wall components of this plant. We are presently studying the structures of the cell wall polysaccharides in Arabidopsis thaliana wild type and the structural features will be compared with those obtained from other sources. Preliminary data suggest the presence of RG-I, RG-II, galacturonans, and xyloglucans. We will continue our work to characterize the Arabidopsis wild type ceil wall, and soon we will initiate studies on the fucose-deficient mutant. We anticipate receiving other sugar-deficient mutants from the Somerville group in the near future.

Until ilow our investigations have been conducted on Arabidopsis plants. No fast replicating s':-jpension cultures of Arabidopsis are available. We are presently trying to oblain a cell suspension of Arabidopsis. Tinis would make our cell wall studies easier. Possibly cell lines of mutant plants will also be obtained.

15. The gluean Inhlibition of virus Infection of tobacco. Collaboration with Professor Bemard Fritig, Centre National de la Recherche Scientifique, Institut de Biologie Moléculaire des Plantes, Strasbourg, France. CCRC investigators: Peter Albersheim, Alan Darvill, and Kevin Brady.

A glucan preparation from the mycelial cell walls of the fungus Phytophthora megasperma f. sp. glycinea protects Nicotianae species against infection by tobacco mosaic virus (TMM). alfalfa mosaic virus, and tomato black ring virus 7 [34j. The glucan preparation protects against viral infection whether the glucan is applied by injection, inoculation, or spraying at any time before, during, or up to eight hours after virus infection. Partial acid hydrolysis, chromatographic purification, and subsequent exhaustive proteinase digestion exclude the possibility that trace amounts of protein contamination are present in the glucan preparation. The glucan preparation does not act directly upon the viral particles or interfere with their disassembly (since protection is aftorded against naked viral RNA), but instead induces changes in the host plant that interfere with initiation of a productive infection. Sensitive ELISA assays that fail to detect any TMV particles in the plant one week after inoculation of the virus have shown that the glucan treatment disrupts viral replication.

Enzyme assays and protein triochemistry studies carried out by our collaborator in Strasbourg, France, Bemard Fritig and coworkers have failed to detect elevated levels of any known plant defense response product following the glucan treatment. No significant increase in the levels of any of several early and late phenylpropanoid pathway enzyrnes, a variety of pathogenesisrelated proteins, hydroxyproline-rich glycoproteins, lignin and lignin-like substances, or callose was observed after glucan treatment. The absence of induction of any known plant defense response enzyme or product led us to conclude that some novel mechanism must be responsible for the viral resistance phenomenon.

We have used radiolabeled nucleic acid probes provided by several laboratories (from all available cloned plant defense response genes) to assay for increased mRNA accumulation levels in tobacco plants sprayed with a $10 \mu \mathrm{g} / \mathrm{ml}$ solution of fungal glucan in water. Our results with the nucleic probes agree with the enzyme results of Fritig's group with one major addition. The glucan treatment does not appreciably alter the mRNA accumulation levels of the genes for phenylalanine ammonia lyase (PAL), chalcone synthase (CHS), cinnamyl alcohol dehydrogenase (CAD), hydroxymethylglutaryl-COA reductase (HMG-COA), hydroxyproline-rich glycoprotein (HRGP), and pathogenesis-related proteins PR-la, PR-B. PR-E, PR-B, chitinase, and $\beta-1,3$ glucanase. All of the above genes have been associated with plant defense responses. However, mRNA levels corresponding to a glycine-rich protein (GRP) gene are increased 8 - to 10 -fold by the glucan treatment. Elevated GRP mRNA levels can be detected within 15 minutes of glucan application; mRNA levels reached a maximum at 2 hours after treatment and then slowly declined through 12 hours. Fritig's group was not able 
to see this response, because there is no known assay or purification scheme for the glycinerich protein.

GRP genes are known to respond extremely rapidly upon plant wounding (increased mRNA levels by 5 minutes after wounding), but the function of the proteins is unknown. GRPs, which are composed of more than $60 \%$ glycine, are thought to be structural components of primary cell walls, but this fraction his not been experimentally established, and their physiological function is completely unknown.

This tobacco GRP gene mRNA is $~ 1450$ nucleotides in length (as determined by Northern blotting). Genomic Southern blots were performed, and, using this Southern blot data, a subgenomic library was constructed (of Nsi I cut DNA 11-12 kb in length), and a full-length genomic clone isolated. This genomic fragment was subcloned into pBluescript and Exonuclease ill nested deletions were constructed (for both strands) to facilitate DNA sequencing. Approximately $95 \%$ of one strand of the gene has been sequenced to date. We are continuing our sequencing of this putentially important plant defense gene.

Phytoalexin accumulation in soybeans can be regulated by a specific hepta- $\beta$-glucoside isolated from fungal cell walls. We have shown that the hepta- $\beta$-giucoside elicitor of phytoalexin accumulation is not active in conferring virus protection. Thus, the glucan elicitor of the GRP gene must be a novel, uncharacterized molecule.

We are attempting to characlerize this heretofore unknown mechanism of plant defense. By taking advantage of the rapid GRP gene response, we propose to consiruct a fusion reporter gene that will facilitate the purification and structural characterization of the biologically active glucan elicitor fragment.

\section{B. Summarles of Student Research Projects Supported by the Center Grant}

1. Studles to Identlfy and purify the receptor of blologically actlve ollgogalacturonides Mark D. Splro.

$\alpha-1,4-$ Oligugalacturonides are involved in a variety of biological responses including defense reactions and morphogenetic changes. In most of these cases the active molecules lie within a narrow size range of degrees of polymerization (DPs) of 12 to 14, and in all cases, the molecules are active at micromolar concentrations. These observations lead us to hypothesize that these molecules are acting through a receptor-mediated pathway and that it should be possible to locate a receptor that binds specificalty to oligogalacturonides in the active size range. We are now in the process of preparing a tyramine and [25]]-labeled tridecagalacturonide to probe for a receptor in microsomes derived from suspension-altered tobacco cells.

Recently, our group in collaboration with the group of Professor Jean Guern (Gif-sur-Yvette, France) has discovered that oilgogalacturonides of DPS 9-14 cause several membrane effects, including depolarization in cultured iobacco cells. These effects may be early steps in the signal transduction pathway resulting from the binding of these molecules. We have chosen suspension-cultured tobacco cells as the source of membrane material in which we will search for a receptor. This system has several advantages. It provides us with a quick and reliable bioassay with which to test the activity of our ligands. The cells are also a convenient source of membranes, as they can be grown up very easily and contain no contaminating chloroplast membranes. Furthermore, a reduced tridecagalacturonide with 12 GalpA residues and a galactitol at the reducing end is active in this system, suggesting that the reducing end of the molecule is not required for recognition by the receptor, and, therefore, our tyramine derivative is likely to be active in this system. 
It is essential that the ligand we use 10 characterize the binding protein is absolutely homogeneous. During the isolation of the tridecagalacturonide from endopolygalacturonasedigested polygalacturonic acid, we discovered that up to six "modified" oligogalacturonides comigrated with each oligogalacluronide separated by high resolution anion-exchange chromatography. These contaminants make up approximately $15 \%$ of the tridecagalacturonide enriched fraction. This fraction was resolved to one major and six minor peaks by Dionex semi-preparative HPAE. These peaks included four oxidized forms of oligogalacturonic acid: GalpA-1,4-[GalpA$]_{7}$-galactaric acid, GalpA- $\%, 4-[G a l p A]_{7}$-tetraric acid, GalpA-1,4-[GalpA] $]_{8}$-galactaric acid and GalpA-1,4-[GalpA $]_{g}-g$ alactaric acid. The two remaining peaks contained 12 and 13 hexosyluronic acid residues, respectively, and they may contain stereoisomers of galacturonic acid. We took advantage of the difference in size of the oxidized contaminants and their consequent differential solubility in aqueous ethanol solutions. By treating the crude mixtures with $11 \%$ ethanol, we were able to selectively precipitate oligogalacturorides in the active size range while leaving the majority of the oxidized contaminants and smaller oligogalacturonides in solution. We were thus able to obtain a very highly purified (>99\%) tridecagalacturonide fraction.

The purified tridecagalacturonide was bound at its reducing terminus to a tyramine group via reductive amination, and the tyramine conjugate was radioactively labeled with [125)] (100 Curies per mmol). Using this method, we successfully conjugated the trigalacturonide with tyramine as confirmed by FAB-MS.

This labeled ligand will be used in binding studies of suspension-cultured tobacco cell microsomal preparations. The specificity of binding activity will be investigated using appropriate controls in competitive binding studies. These controls will include oligogalacturonides outside the active size range (i.e. larger than DP 14 and smaller than DP 9) to test the size requirements for binding as well as $\beta-1,4-D$-oligomannuronides and $\alpha-1,4-L$. oligoguluronides to test the composition requirements for successful binding. These are good negative controls, as they have been shown to be inactive in membrane studies of suspension-cultured tobacco cells and in the tobacco thin cell layer (TCL) bioassay.

2. Generation of monoclonal antibodles to plant cell wall polysaccharldes - Nancy Dunning.

EHorts are currently under way in our laboratory to generate monoclonal antibodies that bind to specific epitopes of plant cell wall polysaccharides. The goal of this research is to obtain polysaccharide-specific antibodies for a variety of experimental applications including the purification of oligo- and polysaccharides, structural characterization of polysaccharides, localization of polysaccharides within cell walls and tissues, and selection of cell wall mutants.

Previous attempts to generate monocional antibodies through traditional spleen cell/myeloma fusion resulted in limited success. The yield of hybridomas secreting antibodies recognizing RG-I was low. Only 12 lines were obtained out of approximately 2,000 hybridomas screened, and the antibodies secreted by these hybridomas fell into only three reactivity groups due to the low immunogenicity of polysaccharides. Our laboratory is developing experimental approaches to increase the number of plant cell wall polysaccharide-specific antibodies. One of our approaches involves the use of recombinant expression libraries for immunoglobulin antibody Fab fragments (Huse et al., 1989, Science 246:1275-1281). We will screen such libraries for immunoglobulin clones with the ability to bind to plant cell wall polysaccharides. We believe this approach will enable us to obtain inore interesting monoclonal antibodies than would be possible through traditional hybridoma technology. The antibody cloning and expression system we will use was developed by Lerner's group (Huse et al., 1989, Science 246:1275-1281) and is marketed by Stratacyte in kit form. In this procedure, antibody cDNAs corresponding to mRNAs are amplified from murine mRNA using primers to conserved regions on the $C_{H} 1(\gamma 1)$ and $V_{H}$ regions of the heavy chain, and $C_{L}(k)$ and $V_{L}(k)$ regions of the light chain. A $\lambda$ phage expression vector is used to generate two CDNA libraries, one for the 
heavy chains and one for the light chains. These libraries are then combined randomly to form a third $\lambda$ library. This combinatorial library will be screened for antibody proteins that bind carbohydrates by using a filter-binding assay analogous to a Western blot, but using labeled oligosaccharides (Cheong et al., 1991, The Plant Cell 3:137-147) as a probe.

Unlike conventional hybridoma technology, this cloning procedure can easily screen thousands of recombinant clones. In addition, since a strong immune response is not strictly required, the technique is particularly well-suited to carbohydrate antigens, which tend to have lower immunogenicity. Initially we will test the utility of this technology by cloning the antibody-producing genes from the spleen cells of a well-immunized mouse and a hybridoma cell line that produces in $\operatorname{lgG}_{1}$ antibody recognizing sycamore xyloglucan. The mouse will be immunized with endopolygalacturonase (EPG), an enzyme known to be highly immunogenic. Poly(A)+ RNA from the spleen cells of this mouse will be used to test the amplification and cloning protocols of the kit. The hybridoma line will be used to develop techniques to screen phage expression libraries using labeled oligosaccharides. Any cloned immunoglobulin genes from this line will provide positive controls for subsequent experiments designed to clone immunoglobulins recognizing other plant cell wall carbohydrates.

To date, total RNA has been isolaied from the spleen of a mouse immunized with EPG. Poly(A)+ RNA was purified by passing total RNA through an oligo dT column. The quality of the poly $(A)+$ RNA will be checked by Northern blot using a gene probe to murine $C_{l}(x)$ chain. The immunogiobulin mRNA present in the poly $(A)+R N A$ will be amplified by PCR and used to construct CDNA libraries. Previously, we have successfully obtained PCR product from spleen polv $(A)+$ RNA. The hybridoma cells are currently being grown to obtain sutficient tissue to isolate total RNA, which will be used to purify poly(A)+ RNA and to construct cDNA libraries. After we obtain recombinarit antibody Fab fragments in these preliminary experiments, we will use the technique to clone carbohydrate-specific antibodies from spleen cells of mice immunized with other plant cell wall-derived carbohydrate antigens.

3. A chromatographlc method for screening enzymes for the abllity to fragment rhainnogalacturonan II, a plant cell wall pectlc polysaccharlde - Que Guo".

High performance anion-exchange chromatography with pulsed amperometric detection was used to screen commercial enzyme preparations and culture media of fungi isolated from soil for the presence of exo- and endoglycanases that fragment thamnogalacturonan II (RG-II), a cell wall pectic polysaccharide. RG-ll-degrading rhamnosidase, arabinosidase, galactosidase, galacturonidase, and glucuronidase activities were found in four commercial enzyme preparations. Small amounts of oligosaccharides were released by treatment of RG-II with a cellulase preparation from Penicilium funiculosum. GLC.MS (c.i. and e.i.) analyses of the methylated oligoglycosyl aiditols derived from the released oligosaccharides provided evidence that the $P$. funiculosum cellulase preparation contains an endogalacturonidase and an endorhamnosidase. Exogalactosidase and exogalacturonidase activities were found in the culture medium of Aspergillus nidulans when that fungus was grown on RG-ll as a carbon source. An enzyme extract of etiolated pea seedlings showed no RG-ll-degrading ability.

'During 1991, Que Gun was awarded an M.S. degree frorn The University of Georgia.

4. Studles on elicltors of plant cell death: the release by pathogen-secreted enzymes of plant cell wall fragments that klll plant cells - Sieven H. Doares

We have hypothesized that plant cell wall fragments are a trigger for hypersensitive cell death, a fundamental defense response of plants that have been challenged by potential pathogens. The goal of this research was to demonstrate that plant cell wall fragments released by plant pathogen-secreted enzymes can kill plant cells. The rice blast fungus, Magnaporthe grisea, was found to secrete, when grown on plant cell walls, a heat-labile activity that killed 
suspension-cultured maize cells. Further, this heat-labile killing activity was shown to release heat-stable maize cell-wall fragments that killed maize cells.

In an attempt to determine whether selected cell wall-degrading enzymes secreted by the fungus were responsible for the heat-labile killing activity, pectin lyase, pectin methylesterase, and a xylanase were purified to homogeneity from the culture filtrate of M. grisea. These enzyrnes individually or logether did not kill suspension-cultured maize cells. However, the xylanase was able to release, to a limited degree, heat-stable maize cell wall fragments that killed maize cells.

The maize cell-wall fragments solubilized by the fungal-secreted heat-labile killing activity were found to be composed primarily of arabinoxylan oligosaccharides, some of which. were feruloylated. The killing activity of the wall fragments was destroyed by base treatment, suggesting that the feruloyl esters were necessary for the killing activity. Purification of the active component was not possible because of the nearly total loss of killing activity during attempted chromatographic separations. The loss of killing activity was shown to result from precipitation or from binding to the walls of the glass vessels of a quantitatively minor component of the fragment mixture.

The results support the hypothesis that plant cell wall fragments are elicitors of the hypersensitive response. However, the fact that the killing activity of the cell wall fragments is due to a quantitatively minor component means that the structural nature of the cell wall fragment that possesses killing activity remains to be determined.

'During 1991, Steven Doares was awarded a Ph.D. degree by The University of Georgia.

5. An Investlgatlon to determine whether pathogenes/s-related (PR) protelns release fungal cell wall ollgosaccharldes that Induce plant defense responses - Kyung-Slk Ham

Infection of many plants with viruses, fungi or bacteria, or treatment with any of several chemicals that stress plants frequently leads to the induction of pathogenesis-related (PR) proteins (Carr et al., 1989, Genetic Engineering: Principles and Methods, Plenum Press, pp. 65-109). Although PR proteins have been widely studied and some of their catalytic functions identified (Carr et al., 1989, Genetic Engineering: Principles and Methods, Plenum Press, pp. 65-109; Bol et al., 1990, Annu. Rev. Phytopathol. 28:113-138), no biological function has been clearly esirblished. We have hypothesized that PR proteins might release biologically active oligosaccharides (oligosaccharins) from fungal cell walls that induce defense responses of plants.

The goals of this project are to determine whether PR proteins release biologically active oligosaccharides from fungal cell walls and to identify the structure of the oligosaccharides. We are focusing our attention on fungal oligosaccharides that either elicit phytoalexin accumulation in the soybean cotyledon bioassay (Darvill et al., 1984, Annu. Rev. Plant Physiol. 35:243-275) or that induce defense against viruses in tobacco (Kopp et al., 1989, Plant Physiol. 90:208-216).

We have shown that PR proteins are induced in soybean leaves by fungal infection and by treatment with mercuric chloride (Ham et al., 1991, Mol. Plant-Microbe Interac., in press). Both $\beta$-1,3-glucanase and chitinase activities were increased following either treatment with mercuric chloride or fungal infection, indicating that some of the induced PR proteins are $\beta$ 1,3-glucanase and chitinase. We purified two basic proteins that could release phytoalexin elicitor-active fragments from fungal pathogen cell walls. It has been demonstrated that these two proteins are PR proteins and that they have $\beta-1,3-$ glucanase activities when assayed with laminarin as a substrate. Thus, these results support the hypothesis that PR proteins release biologically active elicitors from fungal cell walls. We are presently purifyirig oligosaccharide elicitors solubilized from fungal cell walls by purified $\beta-1,3$-glucanase. We propose to 
structurally characterize the elicitors and to determine if different $\beta-1,3$-glucanases release the same, similar, or structurally different elicitors from fungal cell walls.

We have, however, obtained preliminary results that cell wall fragments solubilized from fungal cell walls by a crude protein mixture extracted from mercuric chloride-treated leaves could induce resistance against viral infection in tobacco. We are now conducting experiments to see whether purified $\beta-1,3-g l u c a n a s e s$ release oligosaccharides that protect tobacco against viral infection. We have already determined that these are not the same oligoglucosides that stimulate phytoalexin accumulation.

6. Conformation analysis of a hepta- $\beta$-glucoside ellcltor of phytoalexins by GEGOP calculatlons and Monte Carlo slimulations - Veng Meng Lo

The hepta- $\beta$-glucoside Glc $\beta(1 \rightarrow 6)[G l c \beta(1 \rightarrow 3)] G l c \beta(1 \rightarrow 6)$ Glc $\beta(1 \rightarrow 6)[G l c \beta(1 \rightarrow 3)] G l c \beta(1 \rightarrow 6)$ Glc has been identified in this laboratory as a fungal elicitor of plant phytoalexin accumulation. To gain insight into the interaction of the elicitor with its putative receptor, we are studying the energetically favored conformations of the hepta- $\beta$-glucoside.

The backbone of the heptaglucoside contains four $\beta(1 \rightarrow 6)$ linkages that cause great flexibility in the conformation of the molecule. We pursued two strategies to obtain information on the conformational preferences of the heptaglucoside we pursued two strategies. First, we used a variety of different potential starting conformations and optimized their geometry by energy minimizition using the GEGOP program. As expected, we obtained a multitude of local energy ininima (> 35 conformations within $10 \mathrm{kcal} / \mathrm{mole}$ from the global minimum). Second, we used Metropolis Monte Carlo calculations at $300 \mathrm{~K}$ and $500 \mathrm{~K}$ to characterize the dynamics of the molecule. We found that the $\beta(1 \rightarrow 3)$ branches and the $\Phi$ angles of the backbone show only moderate flexibility. However, the $\Psi$ and $\omega$ angles around the $\beta(1 \rightarrow 6)$ linkages in the backbone show high flexibility with the $\Psi$ angles having values from $60^{\circ}$ to $280^{\circ}$, while conformations around the $\omega$ angles cover all three staggered rotamers. Interestingly, the average overall conformation in a 1,000,000-step Monte Carlo determination shows that the two $\beta(1 \rightarrow 3)$-linked glucosyl residues should be close in space for a significant proportion of the time. We calculate a $5 \%$ NOE between $\mathrm{H} 4$ of one and $\mathrm{H} 2$ of the other $\beta(1 \rightarrow 3)$-linked residue. This indicates that the two branches have fairly well-defined relative orientations. The solution conformation of the hepta- $\beta$-glucoside is continuing.

7. The accumulation of plant defense gene transcripts in response to crude and pure ellcltors - Ivana Gellneo.

When attacked by microorganisms, plant cells, as well as animal cells, activate their defense systems to prevent further invasion by the pathogen. The primary goal of the plant's defense response is to kill the pathogen or at least seriously impair its abilities to destroy the plant. Thus, plants exhibit natural resistance by responding to appropriate signals. Elicitors liberated both from the pathogen and plant itself are chemical signals that can be recognized in the defense cascade. Elicitors are composed of different types of molecules: oligosaccharides, proteins, and lipids (Lawton et al., 1983, Eur. J. Biochem. 129:593-601). As a result of recognition and binding of elicitors, plant cells respond by activating their detense mechanisms that may include: accumulation of phytoalexins, deposition of lignin-like material, accumulation of cell wall hydroxyproline-rich glycoproteins, increase in the activity of hydrolases, such as chitinases and glucanases, accurnulation of pathogenesis-related (PR) proteins, and cnzymes involved in ethylene biosynthesis, among others (Fritig et al., 1987, Plant Resistance to Viruses, Wiley, pp. 92-108).

The goal of our study is to see if there is any difference in gene activation after soybean (Glycine max) is treated with fungal oligosaccharide elicitors of different degrees of purity. To answer this question, the cotyledon assay for elicitor activity was used as described by Ayers et al. (1976, Plant Physiol. 57:751-759). Cotyledons obtained from 9-day-old seedlings were 
used for all experiments. Soybean cotyledons were treated with three different elicitors: autoclaved elicitor isolated from Phytophthora megasperma var. sojae mycelial cell wall as described by Ayers et al. (1976, Plant Physiol. 57:760-765), void glucan (Sharp et al., 1984, J. Biol. Chem. 259:11312-11320), and hepta-B-glucoside (Sharp et al., 1984, J. Biol. Chem. 259.11341-11345). Tiwo distinct determinations were performed on each sample group. The first was performed using different concentrations of each elicitor. The second was accomplished at different time points after olicitation.

Total RNA was isolated from tissue directly underlying the sites of elicitation. Changes in the levels of phenylalanine ammonialyase, chalcone synthase, hydroxyproline-rich glycoprotein, glycine-rich protein, pathogenesis-related protein 1A, pathogenesis-related protein-E, glucanase, chitinase, polygalacturonase and hydroxymethylglutaryl:CoA reductase will be measured by slot-blot hybridization with $\beta 2$ PJ-labeled CDNA probes.

These studies will help us understand the specificity behind activation of plant defense genes as an early component in the expression of defense response.

\section{Studies on blologlcally-actlve $\alpha-1,4$-ollgogalacturonides - Victorla Marta.}

Oligogalacturonide (1,4-linked- $\alpha$-D-galactosyluronic acid) oligosacchärides of DPs $=12-14$ released from plant cell walls are able to induce flowers to form on tobacco explants (Martà et al., 1991, The Plant J. for Cell and Molecular Biol., in press). The TCL bioassay, as modified in this laboratory (Mohnen et al., 1990, Development 108:191-201) has been used to purity the active cell wall component that alters morphogenesis of TCL explants (Eberhard et al., 1989, The Plant Cell 1:747-755). The flower-inducing oligogalacturonides are obtained from endopolygalacturonase (EPG)-ireated cell walls as well as from partially acid-fragmented polygalacturonic acid. Purified pectic polysaccharides, RG-I and RG-II, and several polyanions including oligomannuronides and oligoguluronides, polyglutamic acid, dextran sulfate, and hyaluronic acid did not induce the formation of flowers on the TCL explants. Homogeneous oligogalacturonides with DPs $=16-20$ exhibited no activity either (Marta et al., 1991. The Plant J. for Cell and Mol. Biol., in press).

Oligogalacturonides can also inhibit the pormation of roots on TCLs incubated on a rootinducing medium. As in the case of the induction of flower activity, there is a tight relationship between the inhibition of roots and the degree of polymerization of the oligogalacturonides. Homogeneous oligogalacturonides with DPs $=10-15$ inhibit the formation of roots on TCLs $(=$ $80 \%$ ), while smaller (DPs $=2-9$ ) or larger (DPs $=16-20$ ) oligogalacturonides do not inhibit root formation. A mixture of oligogalacturonides (DPs $=8-16$ ) inhibits the formation of roots on tobacco leaf-disk explants (collaborative project with Professor Felice Cervone).

We have preliminary evidence that bioactive oligogalacturonides are produced in vivo by plant cells. Suspension-cultured sycamore-maple cells secrete extracellular polysaccharides (SEPS) into the culture medium (York et al., 1985, Methods in Enzymology 118:3-40). The structures of these polysaccharides are identical to the corresponding ones from the walls of sycamore-maple cells. We isolated SEPS as described by Stevenson et al. (1986, Plant Physiol. 80.1012-1019). The neutral and acidic SEPS were separated by anionexchange chromatography, and the acidic SEPS were analyzed by high-performance anion-exchange chromatography with pulsed amperometric detection (HPAE-PAD) for the presence of oligogalacturonides. The retention times of the peaks detected by HPAE-PAD were the same as the retention times of standard de-esterified oligogalacturonides with DPS $=8-20$, which had been characterized by fast atom bombardment-mass spectroinetry (FAB-MS). After treatment of the acidic SEPS with purified EPG (that only cleaves between $\alpha-1,4$ galacturonosyl residues), new peaks appeared corresponding to oligogalacturonides with DPS $=1-4$, whereas the ones corresponding to DPS $=8-20$ were absent. These results indicate that acidic SEPS, which are secreted by the sycamore-maple cells in vivo, contain 
oligogalacturonides with DPs $=8-2.0$ that can be converted to small oligomers after treatment with EPG. We are continuing to chemically characterize these putative oligosaccharins.

9. Cloning and characterlzatlon of genes for blologlcally actlve ollgogalacturonide blnding protelns - Brent RIdley.

The goal of this project is to clone a gene for a receptor of biologically active oligogalacturonides (DPS $=12-14$ ). The strategy is to identify CDNA clones that express proteins that bind labeled oligogalacturonides. This approach is based on the success of others in identifying a variety of genes for proteins that bind specific ligands by screening CDNA expression libraries. For example, the genes for calmodulin-binding proteins (Sikela of al., 1987, Proc. Natl. Acad. Sci. 84:3038-3042), the regulatory subunit of CAMP-dependent protein kinase (Lacombe et al., 1987, Gene 58:29-36), and an enhancer binding protein (Singh et al., 1988, Cell 52:415-423; Singh et al., 1989, Biotechniques 7:252-261) have been cloned by screening $\lambda g t 11$ libraries with [125I]-labeled calmodulin, [32P]-labeled CAMP, and [32P]-labeled recognition site DNA, respectively.

The first phase of this project is to label oligogalacturonides with a DP of 13. Oligogalacturonides labeled with [125]] using a method being developed by Mark Spiro (see section 1, above) may be used to screen the expression library. However, we are also attempting to label the tridecagalacturonide with biotin. A model galacturonide, trigalacturonic acid, has been labeled, and attempts to label the pure tridecamer are currently under way. Biotin labeling is idvantageous because biotinylated oligogalacturonides can be used to identify mRNA populations that encode oligogalacturonide-binding proteins. We will translate, in vitro, MRNA isolated from a variety of tissues in the presence of [35S]-methionine. The [35S]-labeled in vitro translation products will be incubated with biotinylated oligogalacturonide, and any protein-oligogalacturonide complexes will be precipitated with strepatvidin-agarose and analyzed by SDS-PAGE (Glass et al., 1989, Cell 59:697-708). These experiments will give us information about the number of different potential oligogalacturonide-binding proteins we can expect from cDNA libraries made from various mRNA sources. In addition, detection of in vitro translated binding proteins will provide evidence for the feasibility of selecting genes for oligogalacturonide receptors by screening $\lambda g t 11$ cDNA exf:ession libraries in E. coli.

A $\lambda$ gt11 expression library constructed from poly A+ mRNA isolated from tobacco thin cell layers (TCLS) will be screened with labeled tridecagalacturonide (Eberhard et al., 1989, The plant Cell 1:747-755). The library will also be screened with oligomannuronic and oligoguluronic acids as controls. This procedure results in the expression of the $\beta$ galactosidase fusion proteins encoded by the library of cDNAs. Clones selected by their production of a fusion protein that selectively binds tridecagalacturonide will be characterized in depth in order to identify a clone that encodes a receptor for biologically active oligogalacturonides. It is possible that genes encoding enzymes that bind oligogalacturonides, such as endopolygalacturonases and pectin methylesterases, will also be identified using this method. These genes would be of interest since the enzymes they encode could release biologically active oligogalacturonides from the cell wall. However, we are more likely to identify the genes for receptors, since enzymes generally have lower binding affinities than receptors.

Clones that express oligogalacturonide-binding proteins will be sequenced with the hope that the function will be suggested by sequence homology to previously characterized receptor. genes. Northern analysis will establish the temporal and tissue specificity of expression of the mRNAs to the clones. Future efforts to obtain other information about the physiological function of oligogalacturonide-binding proteins may include the use of immunocytochemistry, anti-ligand binding site antibodies, and the production of transgenic plants which over-express and under-express mRNA for putative oligogalacturonide receptors. 
10. Characterlzation of an $\alpha$-fucosidase from pea eplcotyls - Chrlstopher Augur.

Enzymes extracted from plant tissues can both release and modify specific xyloglucan oligosaccharides (O'Neill et al., 1988, Phytochem. 27:329-333). Study of xyloglucan oligosaccharides in our laboratory (Augui et al., 1991, Plant Physiol., in press) has provided evidence that specific fucosyl-containing xyloglucan oligosaccharides are able to inhibit auxinstimulated growth of pea stem segments. The terminal $\alpha$-iucosyl residue of xyloglucan oligosaccharides is essential for their growth-inhibiting activity. We have detected and purified from pea stems a cell wall-localized $\alpha$-fucosidase that can remove the terminal fucosyl residue from xyloglucan oligosaccharides thereby destroying their growth-inhibiting activity. This is the first report of the purification to homogeneity of an $\alpha$-fucosicase from plants.

The $\alpha$-fucosidase was purified by selective extraction of the plant tissue and a combination of cation-exchange chromatography and isoelectric focusing. The purification steps were monitored by SDS-PAGE. The enzyme has an apparent molecular weight of $20 \mathrm{Kd}$. We have obtained $N$-terminal and internal amino acid sequences of the enzyme. The amino acid sequence information was used to design degenerate oligonucleotides that were in furn used to amplity via PCR a partial cDNA clone of $\alpha$-fucosidase. The 354 bp cDNA clone was then gel purified and sequenced by the dideoxy method. The $N$-terminal sequence of the fucosidase showed strong homology to trypsin inhibitors.

We are presently using the 354 bp cDNA as a probe to determit.e by Northern analysis whether expressior, of the $\alpha$-fucosidase gene is under auxin control and whether expression is tissue-specific. The $354 \mathrm{bp}$ cDNA probe can also be used to isolate a fucosidase clone from a pea genomic library. We have obtained polyclonal antibodies against $\alpha$-fucosidase that are specific for $\alpha$-fucosidase when analyzed by Western blot using a crude pea extract. The antibodies will be used to localize the enzyme within the plant cell wall through immunogold labeling studies. 
Appendix I: $\quad$ Publications and Abstracts of Presentations of CCRC Research Citing Center Grant Support 
AppendIx I. Publicatlons and Abstracts of Presentallons of CCRC Research CItIng Center Grant Support - September 15, 1990-December 31, 1991

\section{CCRC Publlcatlons}

Published:

O'Neill, M., P. Albersheim, and A. Darvill. 1990. The pectic polysaccharides of primary cell walls. In: Methods in Plant Biochemistry, Vol. 2 (D.M. Dey, ed.), pp. 415-441. Academic Press, London.

Sellers, J., W. York, P. Albersheim, A. Darvill, and B. Meyer. 1990. Identification of the mass spectra of partially methylated alditol acetates by artificial neural networks. Carbohydr. Res. 207:C1-C5.

Kiefer, L.L., W.S. York, P. Albersheim, and A.G. Darvill. 1990. The Siructure of Plant Cell Walls $X X X$. Structural characterization of an arabinose-containing heptadecasaccharide enzymatically isolated from sycamore extracellular xyloglucan. Carbohydr. Res. 197:139. 158.

Von Deyn, W., W.S. York, P. Albersheim, and A. Danill. 1990. 1-akloxyarnino-1-deoxy-alditols, useful u.v.-absorbing derivatives of neutral and acidic oligosaccharides. Carbohydr. Res. 201:135-144.

York, W.S., L.L. Kiefer, A.G. Darvill, and P. Albersheim. 1990. Oxidation of oligoglycosyl alditols during methylation calalyzed by sodium hydroxide and iodomethane in methyl sulfoxide. Carbohydr. Res. 208:175-182.

Doares, S.H., P. Albersheim, arid A.G. Darvill. 1991. An improved method for the preparation of standards for glycosyl-linkage analysis of complex carbohydrates. Carbohydr. Res. 210:311-317.

Hisamatsu, M., G. Impallomeni, W.S. York, P. Albersheim, and A.G. Darvill. 1991. A new undecasaccharide subunit of xyloglucans with two $\alpha$-fucosyl residues. Carbohydr. Res. 211:117-129.

O'Neill, M.A., A.G. Darvill, and P. Albersheim. 1991. The degree of esterification and points of substitution by $O$-acetyl and $O$-(3-hydroxybutanoyl) groups in the acidic extracellular polysaccharides secreted by Rhizobium leguminosarum biovars viciae, trifolii, and phaseoli are not related to host range. J. Biol. Chem. 266:9549-9555.

Carlson, R.W., R. Bhat, and B. Reuhs. 1991. Rhizobium lipopolysaccharides: Their structures and evidence for their importance in the nitrogen-fixing symbiotic infection of their host legumes. In: Biochemical and Genetic Analysis of Gene Expression in Plants and Bacteria (P.M. Gresshoff, ed.). Chapman and Hall, New York and London.

\section{In Press:}

Bhat, U.R., S.K. Bliagyalakshmi, and R.W. Carlson. 1991. Re-examination of the structures of the lipopolysaccharide core oligosaccharides from Rhizobium leguminosarum biovar phaseoli. Carbohydr. Res. In press. 
Hahn, M.G., A. Darvill, P. Albersheirn, C. Bergmann, J.-J. Cheong, A. Koller, V. M. Lo. 1991. Preparation and characterization of oligosaccharide elicitors of phytoalexin accumulation. In: Molecular Plant Pathology: A Practical Appiväth (D.J. Bowles, Ed.). IRL Press. in press.

Hisamatsu, M., W.S. York, A.G. Darvill, and P. Albersheim. 1991. Characterization of seven xyloglucan oligosaccharides containing from seventeen to iwenty glycosyl residues. Cartiohydr. Res. In press.

Koller, A., M.A. O'Neill, A.G. Darvill, and P. Albersheim. 1991. A comparison of the polysaccharides extracted from dried and non-dried walls of suspension-cultured sycamore cells. Phytochem. In press.

Puvanesarajah, V., A.G. Darvill, and P. Albersheim. 1991. Structural characterization of two cligosaccharide fragments formed by the selective cleavage of rhamnogalacturonan II: Evidence for the anomeriv configuration and attachment sites of apiose and 3-deoxy-2. heptulosaric acid. Carbohydr. Res. In press.

Marfà, V., D.J. Gollin, S. Eberhard, D. Mohnen, A. Darvill, and P. ABbersheim. 1991. Oligogalacturonides are able to induce flowers to form on tobacco explants. The Plant $J$. for Cell and Mol. Biol. In press.

Ham, K.-S., S. Kauffmann, P. Albersheim, and A.G. Darvill. 1991. Host-Pathogen Interactions $X X X \mid X$. A soybean pathogenesis-related protein with $\beta-1,3$-glucanase activity releases phytoalexin elicitor-active heat stable fragments from fungal walls. Mol. Plant-Microbe Inter. In press.

\section{CCRC Abstracts}

Albersheim, P. and A.G. Darvill. 1990. "Oligosaccharins - plarit regulatory molecules." XVth International Carbohydrate Symposium, Yokohama, Japan, August 12-17.

O'Neill, M.A., P. Albersheim, and A.G. Darvill. 1990. "Evidence that the O-acylation pattem of the extracellular acidic polysaccharides secreted by Rhizobium leguminosarum biovars is not related to host specificity." International Workshop on Frontiers in Plant and Microbial Glycans, Kyoto, Japan, August 19-21.

Brady, K., P. Albersheim, and A. Darvill. 1990. "A fungal glucan preparation specifically regulates thr expression of a plant glycine-rich protein gene." 5th Intemational Symposium on Molecular Gerietics of Plant-Microbe Interactions, Interlaken, Switzerland, September 914.

Carlson, R., U. Bhat, B. Reuhs, and S. Bhagyalakshmi. 1990. The Rhizobiacae lipopolysaccharides (LPSs)." 5th International Symposium on the Molecular Genetics of Plant-Microbe Interactions, Interlaken, Switzerland, September 9-14.

Kauffmann, S., S.H. Doares, P. Albersheim, and A.G. Darvill. 1990. "Involvement of pathogensecreted enzymes and plant cell wall-derived xylan fragments in plant cell death in the rice blast system." 5th Inlemational Symposium on Molecular Genetics of Plant-Microbe Interactions, Interlaken, Switzerland, September 9-14. 
O'Neill, M.A., P. Albersheim, and A.G. Danill. 1990. "Evidence that the Oacylation pattem of the extracellular acidic polysaccharides secreted by Rhizobium leguminosarum biovars is not related to host specificity." 5th international Symposium on Molecular Genetics of Plant-Microbe Interactions, Interlaken, Switzerland, September 9-14.

Carlson, R.W., R. Bhat, and B. Reuhs. 1991. "Rhizobium lipopolysaccharides: Their structures and evidence for their importance in the nitrogen-fixing symbiotic infection of their host legumes." Second Gatlinburg Symposium, Gatlinburg, Tennessee, January 6-9.

Augur, C., L. Yu, A. Darvill, and P. Abersheim. 1991. "A new bioacilve xyloglucan undecasaccharide and confirmation by chemical synthesis of the structure of a previously characterized bioactive nonasaccharide." Keystone Symposia on Molecular and Cellular Biology, Keystone, Colorado, January 10-17.

Brady, K., A.G. Darvill, and P. Albersheim. 1991. "Specific regulation of a tobacco glycine-rich protein gene by a fungal glucan preparation." Keystone Symposia on Molecular and Cellular Biology, Keystone, Colorado, January 10-17.

Danill, A.G., P. Albersheim, C. Augur, C. Bergmann, K. Brady, J.-J. Cheong, S. Eberhard, M.G. Hahn, V. Marfa, D. Mohnen, and S. Kauttmann. 1991. "Oligosaccharins, oligosaccharide regulatory molecules." 14th International Conference on Plant Growth Substances, Amsterdam, The Netherlands, July 24-29. 
Appendix II: Abstracts of Publications Resulting from Collaborative Projects anú Citing Center Grant Support 
Appendix II. Abstracts of Publlcatlons Resulting from Collaboratlve Projects and Clting Center Grant Support - September 15, 1990-December 31, 1991

\section{Published:}

Brink, B.A., J. Miller, R.W. Carlson, and K.D. Noel. 1990. Expression of Rhlzoblum leguminosarum CFN42 genes for Ilpopolysaccharide in stralns derlved from different $R$. leguminosarum soll Isolates. J. Bacterlol. 172.548-555.

Two mulant derivatives of Rhizobium leguminosarum ANU843 defective in lipopolysaccharide (LPS) were isolated. The LPSs of both mutants lacked O antigen and some sugar residues of the LPS core oligosaccharides. Genetic regions previously cloned from another Rhizobium leguminosarum wild-type isolate, strain CFN42, were used to complement these mutants. One mutant was complemented to give LPS that was apparently identical to the LPS strain ANU843 in antigenicity, electrophoretic mobility, and sugar composition. The other mutant was complemented by a second CFN42 ips genetic region. In this case, the resulting LPS contained O-antigen sugars characteristic of donor strain CFN42 and reacted weakdy with antiserum against CFN42 cells, but did not react detectably with antiserum against ANU843 cells. Therefore, one of the CFN42 Ips genetic regions specifies a function that is conserved between the two $R$. leguminosarum wild-type isolates, whereas the other region, at least in part, specifies a strain-specific LPS structure. Transfer of these two genetic regions into wild-type strains derived from $R$. leguminosarum ANU 843 and $128 \mathrm{C} 53$ gave results consistent with this conclusion. The mutants derived from strain ANU843 elicited incompletely developed clover nodules that exhibited low bacterial populations and very low nitrogenase activity. Both mutants elicited normally developed, nitrogen-fixing clover nodules when they carried CFN42 IDS DNA that permitted synthesis of $O$-antigen-containing LPS, regardless of whether the $O$ antigen was the one originally made by strain ANU843.

Bhat, U.R., H. Mayer, A. Yokola, R.I. Hollingsworth, and R.W. Carlson. 1991. Occurrence of Ilpld A varlants with 27-hydroxyoctacosanolc acld in Ilpopolysaccharldes from the Rhlzoblaceae group. J. Bacterlol. 173:2155-2159.

Lipopolysaccharides (LPSs) isolated from several strains of Rhizobium, Bradyrhizobium, Agrobacterium, and Azorhizcbiuri were screened for the presence of 27-hydroxyoctacosanoic acid. The LPSs from all strains, with the exception of Azorhizobium caulinodans, contained various amounts of this long-chain hydroxy fatty acid in the lipid A fractions. Analysis of the lipid A sugars revealed three types of backbones: those containing glucosamine (as found in Rhizobium meliloti and Rhizobium fredii), those containing glucosamine and galacturonic acid (as found in Rhizobium leguminosarum bv. phaseoli, trifolii, and viciae), and those containing 2,3-diamino-2,3-dideoxyglucose either alone or in combination with glucosamine (as found in Bradyrhizobium japonicum and Bradyrhizobium sp. [Lupinus] strain DSM 30140). The distribution of 27-hydroxyoctacosanoic acid as well as analysis of lipid $A$ backbone sugars revealed the taxonomic relatedness of various strains of Rhizobiaceae.

De Lorenzo, G., Y. Ito, R. D'Ovidlo, F. Cervone, P. Albershelm, and A.G. Darvill. 1990. Host-Pathogen Interactlons XXXVII. Abilities of the polygalacturonase-Inhlbiting protelns from four cultivars of Phaseolus vulgarls to inhlbit the endopolygalacturonases from three races of Colletotrichum IIndernuthlanum. Physlol. Mol. Plant Pathol. 36:421-435.

The ability of endopolygalacturonases isolated from three races of Colletotrichum lindemuthianum to form phytoalexin, elicitor-active oligogalacturonides was studied in the absence and presence of endopolygalacturonase-inhibiting proteins (PGIPS) isolated from four varieties of Phaseolus vulgaris. Endopolygalacturonases (each $40 \mathrm{kDa}$ on SDS-PAGE) from the $\alpha, \beta$, and $\gamma$ races of Colletotrichum lindemuthianum were purified by ion-exchange and fastprotein-liquid gel-permeation chromatographies. The polygalacturonases from the three races formed elicitor-active oligogalacturonides at the same rate. PGIPs (each $41 \mathrm{kDa}$ ) were purified 
from four different cultivars of Phaseolus vulgaris (cvs Great Northern, Pinto, Red Kidney, and Small Red) by affinity chromatography through a Sepharose-endopolygalacturonase column. The PGIPs from all four cvs of $P$. vulgaris were able to increase the lifetimes of phytoalexin elicitor-active oligogalacturonides generated by the endopolygalacturonases. We observed no significant differences in the rate and pattern of formation of elicitor-active oligor, alacturonides by the three enzymes in the presence of each of the four PGIPS. Our data : dicate that the interaction between endopolygalacturonases and their inhibitor proteins does noi per se explain race-cultivar specificity.

O'NellI, M.A., A.G. DarvilI, P. Albershelm, and K.J. Chou. 1990. Structural analysis of an acldlc polysaccharlde secreted by Xanthobacter sp. (ATCC 53272). Carbohydr. Res. 206:289-296.

The structure of an acidic polysaccharide secreted by a Xanthobacter $\mathrm{sp}$. has been investigated by glycosyl-residue and glycosyl-linkage composition analyses, and the characterization of oligoglycosyl fragments of the polysaccharide has been carried out by chemical analyses, $1 \mathrm{H}$-n.m.r. spectroscopy, fast-atom-bombardment mass spectrometry, and electron-impact mass spectrometry. The polysaccharide, which contains O-acetyl groups $(\approx$ $5 \%$ ) that have not been located, has the tetraglycosyl repeating unit 1 and belongs to a group of structurially related polysaccharides synthesized by both Alcalingenes and Pseudomonas species.

$\rightarrow 3)-\beta-D-G l c p-(1-4)-\beta-D-G l c p A-(1 \rightarrow 4)-\beta-D-G l c p-(1 \rightarrow 4)-\alpha-L-M a n p-(1 \rightarrow$

Meyer, B., T. Hansen, D. Nute, P. Albershelm, A. Darvill, W. York, and J. Sellers. 1991. Artiflclal nerual networks identify the $1 \mathrm{H}$-NMR spectra of complex ollgosaccharides. Sclence 251:489-596.

Artificial neural networks can be used to identify hydrogen nuclear magnetic resonance ('H-NMR) spectra of complex oligosaccharides. Feed-forward neural networks with backpropagation of errors can distinguish between spectra of oligosaccharides that differ by only one glycosyl residue in twenty. The artificial neural networks use features of the strongly overlapping region of the spectra (hump region) as well as features of the resolved regions of the spectra (structural reporter groups) to recognize spectra and efficiently recognized $\mathrm{H}$-NMR spectra even when the spectra were perturbed by minor variations in their chemical shifts. Identification of spectra by neural network-based pattern recognition techniques required less than 0.1 second. It is anticipated that artificial neural networks can be used to identify the structures of any complex carbohydrate that has been previously characterized and fur which a 1H-NMR spectrum is available.

Bhat, U.R., R.W. Carlson, M. Busch, and H. Mayer. 1991. Distrlbutlon and phylogenetlc signiflcance of 27-hydroxyoctacosanolc acld In LPSs from bacterla belonging to alpha-2 subgroup of Proteobacterla. Int. J. Syst. Bacterlol. 41:213-217.

Lipopolysaccharides (LPSS) from a number of bacteria belonging to the alpha-2 subgroup of the class Proteobacteria were screened for the presence of 27-hydroxyoctacosanoic acid (27-OH-28:0). With few exceptions, most of the bacteria contained 27-OH28:0 in their lipid A fractions. In addition, some of the bacteria contained other $r$-2-hydroxylated long-chain fatty acids hitherto not reported. The distribution of $27-\mathrm{OH}-28: 0$ was restricted to the alpha-2 subgroup. LPSs from members of the other subgroups (the beta and gamma subgroups), including some well-characterized enterobacterial LPSs, were devoid of $27-\mathrm{OH}$ 28:0. Our results indicate that the presence of $n$-2-hydroxylated long-chain fatty acids in LPSs might be used as a chemophylogenetical marker. 
Stacey, G., J.-S. Su, L.E. Roth, S.K. Bhagyalakshml, and R.W. Carlson. 1991. A Ilpopolysaccharlde mutant from Bradyrh/zoblum japon/cum that uncouples plant from bacterlal differentlatlon. MPMI. 4:332-340.

The Tn5-containing fragment from a non-nodulating mutant of Bradyrhizobium japonicum, strain ML142, was introduced into B. japonicum strain $61 \mathrm{~A} 101 \mathrm{C}$ by marker exchange to construct strain JS314. Strain JS314 failed to nodulate several soybean varieties tested. However, on a fow varieties nodulelike structures were induced to a frequency of $54 \%$ of the plants inoculated. The ultrastructure of these nodules was studied in detail by light and electron microscopy. The nodules were devoid of internal bacteria, possessed central vascular tissue (unlike the lateral v'riscular tissue of a normal nodule), and exhibited localized cell death of epidermal cells. study of the cell surface polysaccharides of strain JS314 revealed that the exopolysaccharide of this strain was identical to that of the wild type. However, the lipopolysaccharide (LPS) of strain JS314 showed gross differences irom that isolated from the wild-type strain. Specifically, the LPS of strain JS314 appeared to lack the high molecular weight LPS1 form, strongly suggesting that the LPS lacks the Ochain. Glycosyl-composition analysis showed that the LPS of mutant JS314 lacked 2,3-di-O-methylrhamnose, 3-O methylrhamnose, fucose, and quinovosamine. These results indicate that LPS I in B. japonicum is essential for bacterial infection of soybean, but is not required to initiate plant cortical cell division, an early plant response to infection.

In Press:

Mathleu, Y., A. Kurkdjlan, H. Xla, J. Guern, A. Koller, M.D. Splro, M.A. O'NellI, P. Albershelm, and A. Darvill. 1991. Membrane responses Induced by ollgogalacturonides in suspenslon-cultured tobacco cells. Plant J. for Cell and Mol. Blol. In press.

Treatment of suspension-cultured tobacco cells with $\alpha-1,4-d$-oligogalacturonides induced a rapid and transient stimulation of $\mathrm{K}^{+}$efflux concomitant with membrane depolarization, alkalinization of the incubation medium, acidification of the cytoplasm, and an influx of $\mathrm{Ca}^{2+}$. Only oligogalacturonides with a degree of polymerization (DP) higher than 9 and lower than 16 were active. The dodecagalacturonide exhibited the greatest ability to induce $\mathrm{K}+$ efflux. The similarity between the structural requirements of oligogalacturonides that induce these shortterm membrane responses and the structural requirements for oligogalacturonides that induce more enduring physiological and morphogenetic responses suggests that one or more of the oligogalacturonide-induced membrane effects generate secondary messages leading to the long-term responses.

Levy, S., W.S. York, R. Stulke-PrIII, B. Meyer, and L.A. Staehelln. 1991. Simulations of the static and dynamic molecular conformations of xyloglucan, the role of the fucosylated sldechain in surface speciflc sidechaln folding. The Plant J. In press.

The hemicellulosic polysaccharide xyloglucan binds with a strong affinity to cellulosic cell wall microfibrils, the resulting heterogeneous network constituting up to $50 \%$ of the dry weight of the cell wall in dicotyledonous plants. To elucidate the molecular details of this interaction, we have performed theoretical potential energy calculations of the static and dynamic equilibrium conformations of xyloglucan using the GEGOP software. In particular, we have evaluated the preferred sidechain conformations of hexa-, octa-, deca- and heptadecasaccharide model fragments of xyloglucan for molecules with a cellulose-like, flat, glucan backbone, and a cellobiose-like, twisted, glucan backbone conformation. For the flat backbone conformation, the determination of static equilibrium molecular conformations revealed a tendancy for sidechains to fold onto one surface of the backbone, defined here as the $\mathrm{HIS}_{1}$ face, in the fucosylated region of the polymer. This folding produces a molecule that is sterically accessible on the opposite 
lace of the backbone, the $\mathrm{H}^{5}$ s face. Typically, this folding onto the $\mathrm{H}_{1}$ s surface is significantly stabilized by favorable interactions between the fucosylated, trisaccharide sidechain and the backbone, with some stabilization from adjacent terminal xylosyl sidechains. In contrast, the trisaccharide sidechain folds onlo the $\mathrm{H}_{4} \mathrm{~S}$ face of xyloglucan fragments with a twisted backbone conformation. Preliminary NMR data on nonasaccharide fragments isolated from sycamore syspension-cultured cell walls are consistent with the hypothesis that the twisted conformation of xyloglucan represents the solution form of this molecule.

Metropolis Monte Carto (MMC) simulations were employed to assess sidechain flexibility of the heptadecasaccharide fragments. Simulations performed on the flat, rigid, backbone xyloglucan indicate that the trisaccharide sidechain is less mobile than the terminal xylosyl sidechains. MMC calculations on a fully relaxed molecule revealed a positive correlation between a specific trisaccharide sidechain orientation and the "flatness" of the backbone glucosyl residues adjacent to this sidechain. These results suggest that the trisaccharide sidechain may play a role in the formation of nucleation sites that initiate the binding of these regions to cellulose.

Based on these conformational preferences, we suggest the following model for the binding of xyloglucan to cellulose. Nucleation of a binding site is initiated by the fucosylated, trisaccharide sidechain that flattens out an adjacent region of the xyloglucan backbone. Upon contacting a cellulose microfibril, this region spreads by stepwise flattening of successive segments of the backbone. Self-association of xyloglucan molecules in solution may be prevented by the low frequency of formation of these nucleation sites and the geometry of the molecules in solution.

\section{Submitted:}

Spalnk, H.P., D.M. Sheeley, A.A.N. van Brussel, J. Glushka, W.S. York, T. Tak, O. Gelger, E.P. Kennedy, V.N. Relnhold, and B.J.J. Lugtenberg. 1991. A novel, highly unsaturated, fatty acld molety of IIpo-ollgosaccharlde signal molecules determines host specificlty of Rhlzoblum leguminosarum. Nature. Submilted.

It is reported here that besides nodABC no other Sym plasmid localized genes are required for the production of such lipo-oligosaccharide molecules. We also show that the NodF and NodE proteins of $R$. leguminosarum biovar viciae are involved in the production of a novel, highly unsaturated, lipid moiety on the oligosaccharide molecules. The presence of this novel lipid, and of an additional O-acetyl modification produced only in the presence of the NodL protein, appears to be essential for the capacity of the lipo-oligosaccharides to induce nodule meristems in vitro on the host plant Vicia sativa.

De Lorerizo, G., F. Cervone, M.G. Hahn, A. Darvill, and P. Albersheim. 1991. Plant cell wall pH prevents lissuin maceratlon and enhances the stabllity of phytoalexin ellcitoractlve ollgogalacturonldes in the presence of a bacterlal endopectate lyase. Physlol. Mol. Plant Path. Submitted.

The abilities of endopectate lyase [ $\alpha-1,4-p o l y-D$-galacturonide lyase], purified from the bacterial plytopathogen Euwinia carotovora, to macerate potato tissue and to produce elicitoractive oligogalacturonides from polygalacturonic acid were studied at various $\mathrm{pH}$ values. The rate at which the lyase depolymerized polygalacturonic acid were studied at various $\mathrm{pH}$ values. The rats which the lyase depolymerized polygalacturonic acid was maximum (100\%) at $\mathrm{pH}$ 9.0 , and wass $10 \%$ at $\mathrm{pH} 8.0$, and $3 \%$ at 7.0. Endopectate lyase macerated potato medullary tissue disks extensively at $\mathrm{pH} 9.0$, to a lesser extent between $\mathrm{pH} 8.0$ and 7.0 , and did not detectably macerntic the disks at $\mathrm{pH}$ values lower than 7.0 or in water $(\mathrm{pH}=6.0)$. Digestion products of polygalacturonic acid treated with endopectate lyase at $\mathrm{pH} 5.75$, the $\mathrm{pH}$ of soybean 
cotyledon exudates, and at $\mathrm{pH} 8.5$, optimum for polygalacturonic acid depolymerization, were tested for phytoalexin-elicitor activity in the soybean cotyledon bloassay. The elicitor activity of the digestion products obtained at $\mathrm{pH} 5.75$ increased during the first $40 \mathrm{hrs}$ of incubation and slowly decreased thereafter as degradation to short elicitor-inactive oligomers progressed. On the other hand, the activity of the digesition products obtained at $\mathrm{pH} 8.5$ dropped to a very low level in less than 20 minutes. The stability of the oligogalacturonides with DP between 10 and 20 , i.e. the oligogalacturonides which exthibit high elicitor activity, was longer than $24 \mathrm{hrs}$ when the digestion of polygalacturonic acid was carried out at pH 5.75, but was less than 20 min when digestions were carried out at $\mathrm{pH}$ 8.5. These studies suggest that, in vivo, endopectate hyases are unlikely to extensively hydrolyze plant cell wall pectin or cause maceration at early stages of pathogenesis, but the lyases are able to generate elicitor-active oligogalacturonides.

Augu., C., L. Yu, K. Sakal, T. Ogawa, P. Sina9, A.G. Darvill, and P. Albershelm. 1991. Further studies of the ablilty of xyloglucan ollgosaccharldes to Inhiblt auxinstimulated growth. Plant Physiol. Submitted.

The structural features required for the ability of xyloglucan oligosaccharides to inhibit 2,4-D-stimulated elongation of pea stem segments have been investigated. A nonasaccharide $(X G 9)^{2}$ containing one fucosyl-galactosyl side chain and an undecasaccharide (XG11) containing two fucosyl-galactosyl side chains were purified from endo-b-1,4-glucanase-treated xyloglucan, which had been isolated from soluble extracellular polysaccharides of suspensioncultured sycamore (Acer pseudoplatanus) cells. An octasaccharide (XG8") was prepared by $\alpha$ xylosidase treatment of XG9. All three oligosaccharides, at a concentration of $0.1 \mu \mathrm{g} / \mathrm{mL}$, inhibited 2,4-D-stimulated growth of pea stem siegments. XG11 inhibited the growth to a greater extent than did XG9 and XG8'. Chemically synthesized nona- and pentasaccharides XG9, $X G 5)$ inhibited 2,4-D-stimulated elongation of pea stems to the same extent as the same oligosaccharides isolated from xyloglucan. A chemically synthesized structurally related heptasaccharide that lacked a fucosyl-galactosyl side chain did not, like the identical heptasaccharide isolated from xyloglucan, significantly inhibit 2,4-D-stimulated growth.

\section{Abstracts of Presentatlons of CCRC Collaborative Work}

Toubart, P., G. Salvi, F. Cenone, G. De Lorenzo, C. Bergmann, A. Darvill, and P. Albersheim. 1990. "Cloning and expression of the polygalacturonase-inhibiting protein (PGIP) of Phaseolus vulgaris." 5th International Symposium on Molecular Genetics of Plant-Microbe Interactions, Interlaken, Switzerland, September 9-14.

Albersheim, P., A.G. Darvill, C. Augur, C. Bergmann, K. Brady, J.-J. Cheon, S.H. Doares, S. Eberhard, T.A. Gruber, M.G. Hahn, V. Marfà, D. Mohnen, S. Kauffmann, F. Cervone, and G. De Lorenzo. 1991. "Oligosaccharins can regulate plant defense, growth, and organogenesis." Keystone Symposia on Molecular and Cellular Biology, Keystone, Colorado, January 10-17.

Martà, V., S. Eberhard, D. Mohnen, A. Darvill, P. Albersheim, F. Cervone, and G. De Lorenzo. 1991. " $\alpha$-1,4-D-oligogalacturonides stimulate the formation of flowers and inhibit the formation of roots in tobacco explants." Keystone Symposia on Molecular and Cellular Biology, Keystone, Colorado, January 10-17.

Toubart, P., G. Salvi, A. Desiderio, F. Cervone, G. De Lorenzo, C. Bergmann, A. Darvill, and P. Albersheim. 1991. "Cloning of the polygalacturonase-inhibiting protein (PGIP) of Phaseolus vulgaris L." Koystone Symposia on Molecular and Cellular Biology, Keystone, Colorado, January 10-17. 
Albersheim, P., A.G. Darvill, V. Marłà, S. Eberhard, D. Mohnen, C. Augur, F. Cervone, and G. De Lorenzo. 1991. "Oligosaccharins can regulate growth and organogenesis in plants." Workshop on Flower Development, Fundación Juan March International Meetings on Biology, Madrid, Spain, March 11-13.

Albersheim, P., A. Darvill, C. Bergmann, F. Cervone, G. De Lorenzo, S.H. Doares, J. Guern, K.-S. Ham, T. Ishii, Y. Ito, S. Kauffmann, Y. Mathieu, M. O'Neill, M. Spiro. 1991. "Oligosaccharide signals in plant-microbe interactions." Symposium on Phytoalexin Hypothesis and Beyond, Dannenfels, Germany, May 5-9. 
Appendix III: Summary of Training Courses

Participants in the Training Courses

Course Evaluation Questionnaire for 1991 Training Courses

Summaries of Course Evaluation Responses 
Appendlx III. Summary of Training Courses: Technlques for Separatlon and Characterization of Complex Carbohydrates - September 15, 1990December 31, 1991

Two training courses were held at the CCRC, sponsored jointly by the USDADDOENSF Plant and Microbial Carbohydrate Center and the NIH Biomedical Carbohydrate Resource Center. The first course (May 13-17, 1991) concentrated on the separation and characterization of glycoprotein carbohydrates, and the second (May 20-24, 1991), on the structural analysis of oligosaccharides. The lab manual was revised for these courses and included selected analytical techniques and a bibliography. The courses were organized and led by Drs. Roberta Merkle, Russell Carlson, and Richard Cummings. The following CCRC staff presented lectures and provided hands-on instruction during the courses:

$\begin{array}{ll}\text { Ramadas Bhat } & \text { Russell Carlson } \\ \text { Richard Cummings } & \text { Terry Dorman-Smith } \\ \text { Roberta Merkle } & \text { Malcolm O'Neill } \\ \text { lzabella Poppe } & \text { David Smith } \\ \text { Herman van Halbeek } & \end{array}$

Participants in the first course were exposed to basic techniques for the isolation and characterization of oligosaccharides. Lectures and demonstrations covered techniques of carbohydrate analysis such as: sugar quantitation by colorimetric assays; lectin blotting; thinlayer chromatography of glycolipids; enzymatic desialylation of glycolipids; overlay assay of glycolipids; separation of individual components from inixtures of oligosaccharides derived from glycoproteins by chromatographic procedures such as amine adsorption HPLS, Dionex HPLC, paper chromatography; lectin affinity chromatography; composition and methylation analyses, gas liquid chromatography; fast atom bombardment-mass spectrometry; and 'H-NMR spectroscopy.

Trainees in the second course learned the lechniques of glycosyl-residue (composition) and glycosyl-linkage (methylation) analyses using gas liquid chromatography-mass spectrometry. Lectures and demonstrations covered other techniques for structural analysis including: fast atom bombardment-mass spectrometry, $1 \mathrm{H}-\mathrm{NMR}$ spectroscopy, and methods for the separation and purification of monosaccharides and oligasaccharides using Dionex HPLC.

Both courses emphasized hands-on laboratory work and included demonstrations and lectures. Seven people participated in the first course and ten in the second. (We had limited each course to 10 participants, and experience with basic biochemical techniques was a prerequisite for participation.) The cost of registration per course was $\$ 250$ for individuals from non-profit institutions, $\$ 500$ for others. The cost of travel, lodging, and food was not included. Participants were chosen on the basis of their potential for benefitting from the course, i.e., for application of the techniques learned to their own projects. We asked each group of participants to evaluate their course, and the responses were positive and enthusiastic. A list of participants in each course and their affiliations is included in this appendix, as well as summaries of participants' comments evaluating the courses.

Advertisements for the courses were placed in the following publications:

ASPP

$\begin{array}{lll}\text { Bio/Technology } & \text { 1/3-page } & \text { March } \\ \text { Cell } & 1 / 2 \text {-page } & \text { March 22 } \\ \text { Science } & \text { 1/3-page } & \text { March 15 }\end{array}$


Particlpants in Training Course 1: Separatlon and Characterlzatlon of Glycoproteln Carbohydrates - May 13-17, 1991

Ms. Carol Arnosti, Graduate Student Woods Hole Oceanographic Institution

Chemistry Department

Woods Hole, MA

Dr. Sheilah Asher

Amgen, Inc.

Thousand Oa'ss, CA

Dr. Paul G. James, Research Scientist

Glycomed, Inc.

Alameda, CA

Dr. Ludmila Novik, Research Scientist

Miles Inc., Cutter Biological

Berkeley, CA

Dr. Mark C. Plucinsky, Research Scientist

Centocor

Malvern, PA

Dr. Maryline Sharp, Postdoctoral Research Associate

Washington University School of Medicine

Department of Pediatrics

St. Louis, MO

Dr. Joseph Andrade, Research Scientist

Baxter Hyland

Duarte, CA

Partlclpants In Tralning Course 2: Structural Analysis of Ollgosaccharldes - May 20-24, 1991

Ms. Carol Arnosti, Graduate Student

Woods Hole Oceanographic Institution

Chemistry Department

Woods Hole, MA

Dr. Alexis Eberendu, Research Scientist

Carrington Labs, inc.

Dallas, $T \mathbf{X}$

Dr. Sylvia Hanwig, Research Scientist

UCLA Center for Health Sciences

Department of Medicine

Los Angeles, CA

Dr. David Hawke, Research Scientist

Applied Biosystems

Foster City, CA 
Dr. Paul James, Research Scientist

Glycomed, Inc.

Alameda, CA

Dr. Mark C. Plucinsky, Research Scientist

Centocor

Malvern, PA

Ms. Rebecca Robbins, Graduate Student

UCLA

Department of Biology

Los Angeles, CA

Dr. Gary N. Rogers, Research Scientist

Amgen

Thousand Oaks, CA

Dr. Dave Sertl, Research Scientist

Ross Laboratories

Columbur, $\mathrm{OH}$

Dr. P.K. Tsai, Research Scientist

Merck Sharp \& Dohme

West Point, PA 


\section{Training Course Evaluation Questlonnaire}

1. Was the course laught at the proper level, too basic, or too advanced?

2. Which laboratory exercises were the most useful to you? Were there any you would prefer that we did not cover?

3. In what ways could this course be improved? Would you like to see particular techniques covered that we did not include?

4. Was the laboratory manual organized well? Were the procedures easy to follow?

5. Was the laboratory environment easy to work in? Did you receive enough help during the laboratory exercises? Too much help?

6. Was it useful to have lectures related to the lab exercises?

7. Did the lectures cover topics you were interested in? Would you like us to cover other topics?

8. Did you find it useful to have trainees work in pairs?

9. Please make any other comments regarding this course. 


\section{Summary of Course Evaluation Responses \\ Course \#1 - Separatlon and Characterlzatlon of Glycoproteln Carbohydrates}

May 13-17, 1991

The majority of the participants thought that the course was taught at an appropriate level, that the laboratory manual was well organized and would serve as a good reference source, and that the laboratory environment was easy to work in. They though the procedures were easy to follow, that it was helptul to work in pairs, and that they received enough assistance while performing the laboratory exercises. The participants thought it was useful to have lectures related to the laboratory exercises, and, in fact, some commented that they would like to have a broader range of tcpics included.

Suggestions for improvements included adding more exercises such as sequential exoglycosidase digestions and pieparation of lectin affinity columns, and having more formal follow-up discussions of some of the exercises.

\section{Summary of Course Evaluatlon Responses}

Course \#2 - Methods for the Analysls of Complex Carbohydrates

May 20-24, 1991

The participants in this course thought that it was taught at the proper level, that the laboratory exercises were very useful, that the laboratory manual was well organized, the laboratory environment was good, the lectures were good, the topics covered were appropriate and useful, and that it was beneficial to work in pairs.

The participants would have liked to have had laboratory exercises in NMR, FAB-MS, and DIONEX. Also, they would like to have more discussion after the laboratory exercises and more lectures on NMR. 
Appendix N: Summary of Analytical Services

CCRC Charges for Analytical Services

Analysis Requests and Reports from September 1990-Present 
Following is a copy of the advertisement for the analytical services offered by the Center for Plant and Microbial Complex Carbohydrates. This ad was placed in the following publications:

$\begin{array}{lcl}\text { ASM } & \text { 1/4-page } & \text { March } \\ \text { ASPP } & & \\ \text { Bio/Technology } & \text { 1/4-page } & \text { February } \\ \text { Cell } & 1 / 4 \text {-page } & \text { February 22 } \\ \text { J. Biol. Chem. } & 1 / 4 \text {-page } & \text { February 25 } \\ \text { Science } & 1 / 4 \text {-page } & \text { February 8 }\end{array}$

Posters with attached inquiry cards are taken to meetings attended by CCRC scientists announcing the availasility of services offered by the Center for Plant and Microbial Complex Carbohydrates. We have also submitted flyers to the organizers of scientific meetings to be included in the registration packets for the meetings. These advertisements have resulted in inquiries about the services. 


\section{ANALYTICAL SERVICES}

provided by the

\section{COMPLEX CARBOHYDRATE RESEARCH CENTER (CCRC)}

The CCRC of The University of Georgia has been designated a Resource Center for Bioncdical Complex Carbohydrate Science (sponsored by the NIH) and a Plant Science Center for the study of Plant and Microbial Carbohydrates (sponsored by the USDA, DOE, and NSF). These centers provide analytical assistance for scientists in university, industrial, and government laboratories carrying out nonproprietary research on the complex carbohydrates derived from animal, plant and microbial sources. The routine scrvices that are offered include (1) glycosyl composition analysis, (2) glycosyl linkage analysis and (3) molecular weight determinations. The CCRC instrumentation used to provide these services includes gas liquid chromatography, gas liquid chromatography-mass spectrometry, fast atom bombardment-mass spectrometry, 250- and $500-\mathrm{MHz}$ ${ }^{1} \mathrm{H}-\mathrm{NMR}$, and ${ }^{13} \mathrm{C}$-NMR spectroscopy. Investigators may wish to establish a collaboration with scientists in the Resource Center to carry out more extensive characterization of their samples such as glycosyl sequence analysis. Those wishing to use the services of the CCRC should contact the Technical Directors for further information regarding the criteria and cost for sample analysis. Please do not submit samples without prior agreement. Address inquiries to: Dr. Roberta K. Merkle, Technical Director for Biomedical Carbohydrates, or Dr. Russell W. Carlson, Technical Director for Plant and Microbial Carbohydrates, Complex Carbohydrate Research Center, 220 Riverbend Road, The University of Georgia, Athens, Georgia 30602. Facsimile: 404-542-4412. Phone: 404-542-4405. 
providud by the

\section{COMPLEX CARBOHYDRATE RESEARCH CENTER}

A DOE/NSF/USOA PLANT SCIENCE AND NOH BIOMEDICAL. RESOURCE CENTER

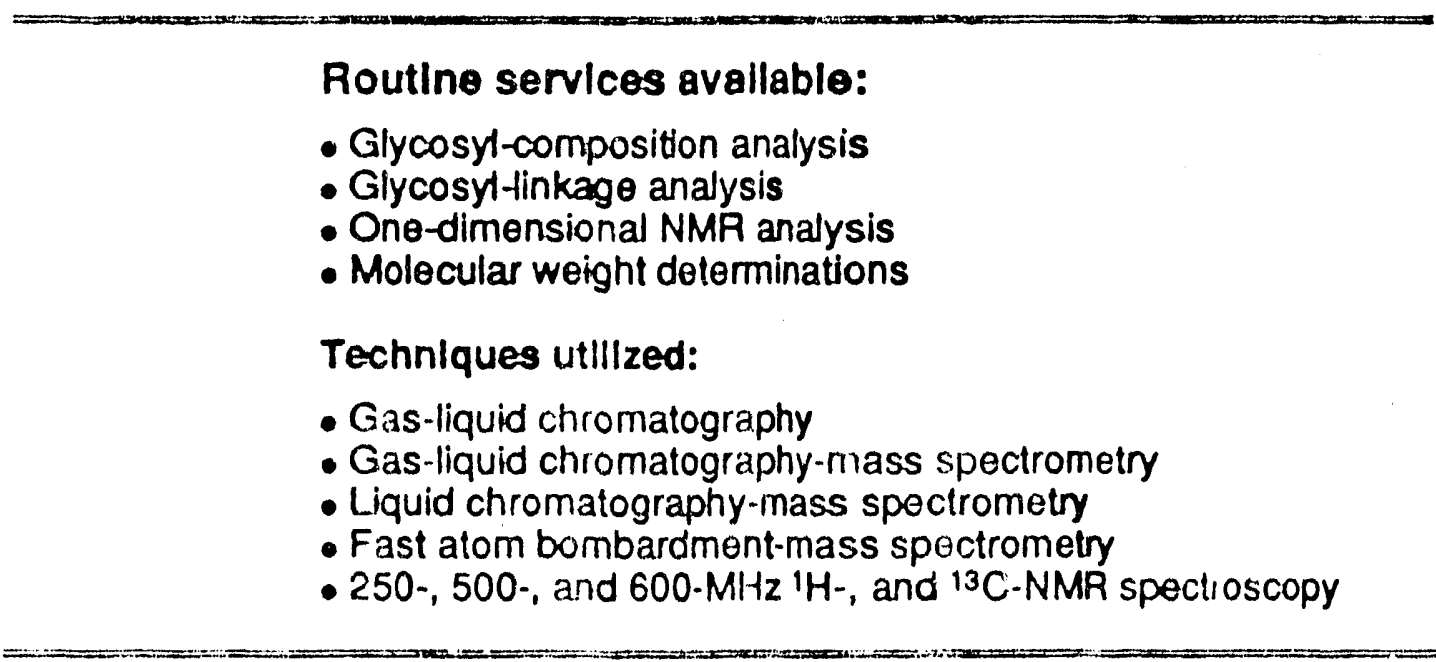

\section{A UNIQUE CONCENTRATION OF INTERDISCIPLINARY EXPERTISE AND STATE-OF-THE-ART INSTRUMENTATION}

Send the attached card for further information on the services available (the cost for sample analysis, how to prepare your sample, etc.). Contact the appropriate technical director prior to submitting any samples. Non-routine services and more extensive collaborative investigations can be set up on a case-by-case basis.

\section{Dr. Russell W. Carlson, Technlcal Director-Plant \& Mlcroblal Carbohydrates} Dr. Roberta K. Merkle, Technlcal Director-Blomedlcal Carbohydrates

Complex Carbohydrate Research Center, The University of Georgia 220 Riverbend Road, Athens, Georgia 30602 USA

Tel.: 404-542-4402 Facsimile: 404-542-4412

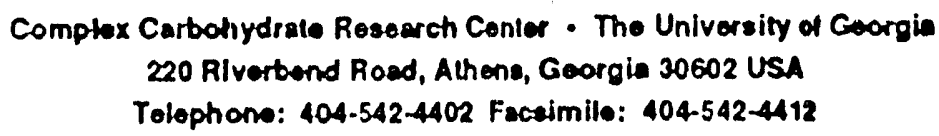

Please send me information on the analytical services available at the Complex Cartohydrate Research Center. Namo:

InstitutiondepartnenvCompary:

Maiting Address:

Tolephono No.: Facsimile:

I ann working in $\square$ plant'miorobial $\square$ animal cell carbohydrates and am interested in

D I would also like to recoire information on the content, capabilitios, and purchase cost of the Complex Carbohydrato Structura Database and its search program, CarbBank. 


\section{COMPLEX CARBOHYDRATE RESEARCH CENTER}

\section{CHARGES FOR ANALYTICAL SERVICES}

\begin{tabular}{lcr} 
Type of Analysls & $\begin{array}{c}\text { Charge per Sample } \\
\text { Government, Universities \& } \\
\text { Other Non-profit Groups }\end{array}$ & $\begin{array}{c}\text { For-profit } \\
\text { Groups }\end{array}$ \\
\hline Glycosyl composition analysis & $\$ 100$ & $\$ 250$ \\
Glycosyl linkage analysis & 100 & 250 \\
One-dimensional NMR & 100 & 250 \\
FAB-MS & 100 & 250 \\
Total for all of the above: & $\$ \frac{100}{400}$ & $\$ 1,000$
\end{tabular}




\begin{tabular}{|c|c|c|c|c|}
\hline Name & Sample Type & Analysis Type & $\begin{array}{c}\text { Number of } \\
\text { Samples }\end{array}$ & Date \\
\hline $\begin{array}{l}\text { D. de Jong } \\
\text { Dept. of Bacteriology } \\
\text { Univ. of Wisconsin } \\
\text { Madison, WI }\end{array}$ & $\begin{array}{l}\text { Glycoprotein samples } \\
\text { from gliding bacteria }\end{array}$ & Composition & 2 & $6 / 1 / 90$ \\
\hline $\begin{array}{l}\text { J. Streeter } \\
\text { Dept. of Agronomy } \\
\text { OH State Univ. } \\
\text { Wooster, OH }\end{array}$ & $\begin{array}{l}\text { Carbohydrate slime } \\
\text { from soybean samples }\end{array}$ & Composition & 5 & $6 / 1 / 90$ \\
\hline $\begin{array}{l}\text { J. Puhlman } \\
\text { CCRC } \\
\text { Univ. of GA } \\
\text { Alhens, GA }\end{array}$ & Malloheptaaminitol & $\begin{array}{l}1 \mathrm{H} \text { - and }{ }^{13} \mathrm{C} \text { - } \\
\text { NMR }\end{array}$ & 1 & $6 / 19 / 90$ \\
\hline $\begin{array}{l}\text { J. de Stefano } \\
\text { Univ. of Cincinatti } \\
\text { Medical Ctr. } \\
\text { Dept. of Anatomy } \\
\text { and Cell Biology } \\
\text { Cincinnati, OH }\end{array}$ & Alditol acetates & GC/MS & 23 & $6 / 21 / 90$ \\
\hline $\begin{array}{l}\text { D. Sertl } \\
\text { Ross Laboratories } \\
\text { Columbus, OH }\end{array}$ & Ross Lab. & $\begin{array}{l}\text { Composition, } \\
\text { methylation }\end{array}$ & 2 & $8 / 2 / 90$ \\
\hline $\begin{array}{l}\text { A. Sturm } \\
\text { Friedrich Miescher } \\
\text { Institut } \\
\text { Basel, Switzerland }\end{array}$ & $\begin{array}{l}\text { Secreted carrot } \\
\text { glycoprotein }\end{array}$ & Composition & 10 & $8 / 20 / 90$ \\
\hline $\begin{array}{l}\text { P. Atreya } \\
\text { Dept. of Plant Path. } \\
\text { Univ. of Kentucky } \\
\text { Lexington, KY }\end{array}$ & $\begin{array}{l}\text { Glycoprotein from } \\
\text { tobacco leaves }\end{array}$ & Composition & 1 & $8 / 27 / 90$ \\
\hline $\begin{array}{l}\text { M. Fuller } \\
\text { Dept. of Botany } \\
\text { Univ. of Georgia } \\
\text { Athens, GA }\end{array}$ & Fungal glucan & Methylation & 1 & $10 / 4 / 90$ \\
\hline $\begin{array}{l}\text { J. Puhlman } \\
\text { CCRC } \\
\text { Univ. of Georgia } \\
\text { Athens, GA }\end{array}$ & Synthetic glucan & NMR & 1 & $10 / 11 / 90$ \\
\hline $\begin{array}{l}\text { J. Puhlman } \\
\text { CCRC } \\
\text { Univ. of Georgia } \\
\text { Athens, GA }\end{array}$ & Maltoheptose & ${ }^{1} \mathrm{H}-$ and ${ }^{13} \mathrm{C}-\mathrm{NMR}$ & 1 & $10 / 17 / 90$ \\
\hline
\end{tabular}


Name

M. Nicder

ESCA Genetics Corp.

San Carlos, CA

J. Streeter

Dept. of Agronomy

Ohio State Univ.

Wooster, $\mathrm{OH}$

S. M. Lim

Dept. of Plant

Path. and Genetics

Univ. of Illinois

Unbana, IL

K. Fredrikson

Dept. of Plant

Biochemistry

Univ. of Lund

Lund, Sweden

R. van Huystee

Dept. of Plant Sci.

Univ. of Western

Ontario

London, Ontario

Canada

A. Junkins

Univ. of Wisconsin

Dept. of Food

Microbiology and

Toxicology

Madison, WI

D. Domozych

Dept. of Biology

Skidmore College

Saratoga Springs, NY

$H$. Prechel

Biologie VI (Genetik)

Universitat Bielefeld

Germany

J. Hyatt

Eastman Chemical

Company

Kingsport, TN

H. Grimes

Dept. of Botany

Washington State Univ.

Pullman, WA
Number of

Sample Type

Analysis Typo

Samples

Composition

2

$10 / 22 / 90$

from plant tissue

culture

Soybean nodule

Composition

2

$10 / 24 / 90$

slime

Composition,

1

$11 / 5 / 90$

phytotoxin

linkage, NMR

Methylation

1

$11 / 7 / 90$

produced by glucan

synthase from cauli-

flower

Peroxidase

oligosaccharides

Composition

Linkage

2

$12 / 6 / 90$

1

2

$12 / 10 / 90$

linkage, NMR

Algal-scale

Composition,

methylation

1

$01 / 10 / 91$

Rhizobium legumino-

sarum biovar

viciae lipopoly-

saccharide

Glucomannin

Composition,

1

$11 / 14 / 90$

methylation

Glycoprotein

Composition

1

$02 / 19 / 91$ 


\begin{tabular}{|c|c|c|c|c|}
\hline Name & Sample Type & Analysis Type & $\begin{array}{c}\text { Number of } \\
\text { Samples }\end{array}$ & Date \\
\hline $\begin{array}{l}\text { J. Hyatt } \\
\text { Eastman Chemical Co. } \\
\text { Kingsport, TN }\end{array}$ & $\begin{array}{l}\text { Commercial } \\
\text { cellulose } \\
\text { acetates }\end{array}$ & Composition & 5 & $02 / 19 / 91$ \\
\hline $\begin{array}{l}\text { S. Kadis } \\
\text { Dept. of Medical } \\
\text { Microbiology } \\
\text { Univ. of Georgia } \\
\text { Athens, GA }\end{array}$ & $\begin{array}{l}\text { Pasteurella } \\
\text { lipopolysaccharides }\end{array}$ & Composition & 2 & $02 / 21 / 91$ \\
\hline $\begin{array}{l}\text { L. Hadwiger } \\
\text { Dept. of Plant Path. } \\
\text { Washington State Univ. } \\
\text { Pullman, WA }\end{array}$ & $\begin{array}{l}\text { Fungal pathogen } \\
\text { elicitor }\end{array}$ & $\begin{array}{l}\text { Composition, } \\
\text { NMR }\end{array}$ & 4 & 03/06/91 \\
\hline $\begin{array}{l}\text { T. Irizana } \\
\text { Dept. of Pathobiology } \\
\text { Virginia-Maryland } \\
\text { Regional College of } \\
\text { Vet. Med. } \\
\text { VPI } \\
\text { Blacksburg, VA }\end{array}$ & Haemophilus somnus & $\begin{array}{l}\text { Composition, } \\
\text { Fatty acid }\end{array}$ & 4 & 03/06/91 \\
\hline $\begin{array}{l}\text { J. Hyatt } \\
\text { Eastman Chemical Co. } \\
\text { Kingsport, TN }\end{array}$ & $\begin{array}{l}\text { Fractions of a commercial } \\
\text { cellulose acetate }\end{array}$ & Composition & 5 & $03 / 20 / 91$ \\
\hline $\begin{array}{l}\text { C. Read Kensil } \\
\text { Cambridge Biotech } \\
\text { Worcester, MA }\end{array}$ & Quillaja saponaria & Linkage & 1 & 03/20/91 \\
\hline $\begin{array}{l}\text { S. Kellog } \\
\text { Dept. of Bacteriology } \\
\text { Univ. of Idaho } \\
\text { Moscow, ID }\end{array}$ & $\begin{array}{l}\text { Gram positive } \\
\text { Bacteria }\end{array}$ & Composition & 1 & $03 / 22 / 91$ \\
\hline $\begin{array}{l}\text { M. Brown } \\
\text { Dept. of Botany } \\
\text { Univ. of TX } \\
\text { Austin, TX }\end{array}$ & $\begin{array}{l}\text { In vitro synthesized } \\
\text { glutens }\end{array}$ & Linkage & 3 & $03 / 22 / 91$ \\
\hline $\begin{array}{l}\text { C. Reed Kensil } \\
\text { Natural Products } \\
\text { Cambridge Biotech } \\
\text { Worcester, MA }\end{array}$ & Saponin & Composition & 2 & $04 / 16 / 91$ \\
\hline $\begin{array}{l}\text { J. van Etten } \\
\text { Dept. of Plant } \\
\text { Pathology } \\
\text { Univ. of NE } \\
\text { Lincoln, NE }\end{array}$ & $\begin{array}{l}\text { Chlorella virus } \\
\text { protein }\end{array}$ & Composition & 1 & 04/16/91 \\
\hline
\end{tabular}




\begin{tabular}{|c|c|c|c|c|}
\hline Name & Sample Type & Analysis Type & $\begin{array}{l}\text { mber of } \\
\text { amples }\end{array}$ & Date \\
\hline $\begin{array}{l}\text { E. Shotts } \\
\text { Dept. of Med. Micro. } \\
\text { Univ. of GA } \\
\text { Athens, GA }\end{array}$ & An Algo suspension & Glycosyl composition & 1 & $04 / 24 / 91$ \\
\hline $\begin{array}{l}\text { J. A. Raymond } \\
\text { Dept. of Biological } \\
\text { Sciences } \\
\text { Univ. of South AL } \\
\text { Mobile, AL }\end{array}$ & $\begin{array}{l}\text { Nitschia stellata } \\
\text { glycoproteln }\end{array}$ & Glycosyl composition & 1 & $04 / 24 / 91$ \\
\hline $\begin{array}{l}\text { K. Fredrikson } \\
\text { Dept. of Plant } \\
\text { Biochemistry } \\
\text { University of Lunde } \\
\text { L.unde, Sweden }\end{array}$ & Polyglucan & $\begin{array}{l}\text { Glycosyl composition } \\
\text { L.Inkage }\end{array}$ & $\begin{array}{l}4 \\
4\end{array}$ & $05 / 08 / 91$ \\
\hline $\begin{array}{l}\text { E. Hyman } \\
3525 \text { Prytania Str. } \\
\text { Suite } 220 \\
\text { New Orleans, LA }\end{array}$ & Bacterial sample & Glycosyl composition & 1 & $05 / 08 / 91$ \\
\hline $\begin{array}{l}\text { T. Inzana } \\
\text { Dept. of Pathobiology } \\
\text { Virginia-Maryland } \\
\text { Regional College of } \\
\text { Veterinary Medicine } \\
\text { VPI } \\
\text { Blacksburg, VA }\end{array}$ & Lipopolysaccharide & $\begin{array}{l}\text { Glycosyl composition } \\
\text { and fatty acid }\end{array}$ & 1 & 05/08/91 \\
\hline $\begin{array}{l}\text { R. Pressey } \\
\text { Richard Russell } \\
\text { Research Center } \\
\text { Athens, GA }\end{array}$ & Giycoprotein & Glycosyl composition & 1 & $05 / 08 / 91$ \\
\hline $\begin{array}{l}\text { N. Carpita } \\
\text { Dept. of Botany and } \\
\text { Plant Pathology } \\
\text { Purdue Univ. } \\
\text { West Lafayette, IN } 47907\end{array}$ & Polyglycuronic acid & NMR & 1 & $05 / 24 / 91$ \\
\hline $\begin{array}{l}\text { J. Hyatt } \\
\text { Eastman Chemical Co. } \\
\text { Kingsport, TN }\end{array}$ & Cellulose acetate & Glycosyl composition & 3 & $05 / 31 / 91$ \\
\hline $\begin{array}{l}\text { S. Kadis } \\
\text { Dept. of Med. Micro. } \\
\text { UGA Vet. Med. } \\
\text { Athens, GA }\end{array}$ & Pastuerella LPS & Composition & 3 & $05 / 31 / 91$ \\
\hline $\begin{array}{l}\text { R. Pressey } \\
\text { USDA Russell Rsch. Ctr. } \\
\text { Athens, GA }\end{array}$ & Plant glycoprotein & Glycosyl composition & 2 & $05 / 31 / 91$ \\
\hline
\end{tabular}




\begin{tabular}{|c|c|c|c|c|}
\hline Name & Sample Type & Analysis Type & $\begin{array}{l}\text { mber of } \\
\text { amples }\end{array}$ & Date \\
\hline $\begin{array}{l}\text { F. Voragen } \\
\text { Dep. of Food Sci. } \\
\text { Wageningen Agricultural } \\
\text { University } \\
\text { P.O.B. } 81296700 \text { E.V. } \\
\text { Wageningen, The Netherlan }\end{array}$ & Pectic cell wall fraction & Glycosyl composition & 1 & $05 / 31 / 91$ \\
\hline $\begin{array}{l}\text { N. V. Padhye } \\
\text { Food Research Institute } \\
1925 \text { Willow Dr. } \\
\text { Madison, WI }\end{array}$ & $\begin{array}{l}\text { Glycoprotein from } \\
\text { E. coli }\end{array}$ & Composition & 1 & $06 / 19 / 91$ \\
\hline $\begin{array}{l}\text { J. van EHen } \\
\text { Dept. of Plant Path. } \\
\text { Univ. of Nebraska } \\
\text { Lincoln, NE }\end{array}$ & $\begin{array}{l}\text { Capsid protein from six } \\
\text { Chlorella-virus PBCB-10 } \\
\text { types }\end{array}$ & Composition & 6 & $06 / 19 / 91$ \\
\hline $\begin{array}{l}\text { V. Puvanesarajah } \\
\text { ABC Labs, Inc. } \\
\text { P.O. Box } 1097 \\
\text { Columbia, MO }\end{array}$ & Herbicide metabolite & $\begin{array}{l}\text { FAB-MS and } \\
\text { GC-MS }\end{array}$ & 1 & $07 / 10 / 91$ \\
\hline $\begin{array}{l}\text { A. Collmer } \\
\text { Dept. of Plant Path. } \\
\text { Cornell Univ. } \\
\text { Ithaca, NY }\end{array}$ & $\begin{array}{l}\text { Pectate lyase isozyme } \\
\text { from Enwinia chrysanthemi }\end{array}$ & Composition & 1 & $07 / 12 / 91$ \\
\hline $\begin{array}{l}\text { G. C. Daily } \\
\text { Stanford Univ. } \\
\text { Dept. of Biological } \\
\text { Sciences } \\
\text { Stanford, CA }\end{array}$ & Sap from a willow shrub & Composition & 1 & $07 / 12 / 91$ \\
\hline $\begin{array}{l}\text { J. Chatterton } \\
\text { USDA Northern Plains } \\
\text { Area } \\
\text { Forest and Range Rsch. } \\
\text { Utah State Univ. } \\
\text { Logan, UT }\end{array}$ & $\begin{array}{l}\text { Tetrasaccharide from } \\
\text { Bromus tectorum }\end{array}$ & $\begin{array}{l}\text { Methylation and } \\
\text { FAB-MS }\end{array}$ & 1 & $07 / 15 / 91$ \\
\hline $\begin{array}{l}\text { C. R. Kensil } \\
\text { Cambridge Biotech } \\
\text { Worcester, MA }\end{array}$ & Triterpine glycoside & $\begin{array}{l}\text { Glycosyl composition, } \\
\text { linkage }\end{array}$ & 1 & $07 / 15 / 91$ \\
\hline $\begin{array}{l}\text { K. E. Vogele } \\
\text { The Wistar Institute } \\
\text { Philadelphia, PA }\end{array}$ & Quilliac acid & $\begin{array}{l}\text { Composition, } \\
\text { linkage }\end{array}$ & 1 & $07 / 24 / 91$ \\
\hline $\begin{array}{l}\text { D. L. Hendricks } \\
\text { Western Cotton Rsch. Lab } \\
\text { USDA-ARS } \\
\text { Phoenix, AZ }\end{array}$ & $\begin{array}{l}\text { Fractions from the honey } \\
\text { dew of the sweet potato } \\
\text { white fly Bemisia tabaci }\end{array}$ & Methylation & 2 & $07 / 28 / 91$ \\
\hline
\end{tabular}




\begin{tabular}{|c|c|c|c|c|}
\hline Name & Sample Type & Analysis Type & $\begin{array}{l}\text { mber of } \\
\text { amples }\end{array}$ & Date \\
\hline $\begin{array}{l}\text { J. Hyatt } \\
\text { Eastman Chemical Co. } \\
\text { Kingsport, TN }\end{array}$ & $\begin{array}{l}\text { Commercial cellulose } \\
\text { acetate Iractions }\end{array}$ & $\begin{array}{l}\text { Glycosyl composition } \\
\text { methylation }\end{array}$ & $\begin{array}{l}4 \\
1\end{array}$ & $07 / 28 / 91$ \\
\hline $\begin{array}{l}\text { C. Bergmann } \\
\text { CCRC } \\
\text { Athens, GA }\end{array}$ & Endopolygalacuronase & Glycosyl composition & 1 & $07 / 29 / 91$ \\
\hline $\begin{array}{l}\text { W. Burks } \\
\text { Dept. of Pedlatrics } \\
\text { Univ. of Arkansas for } \\
\text { Medical Sclences } \\
\text { Arkansas Children's Hospital } \\
\text { Little Rock, AR }\end{array}$ & Peanut glycoproteins & Glycosyl composition & 2 & $07 / 29 / 91$ \\
\hline $\begin{array}{l}\text { J. Petter } \\
\text { SE Pcultry Rsch. Lab } \\
\text { Athens, GA }\end{array}$ & $\begin{array}{l}\text { Cell wall fraction from a } \\
\text { chicken pathogen }\end{array}$ & Composition & 1 & $07 / 28 / 91$ \\
\hline $\begin{array}{l}\text { R. V. van Huystee } \\
\text { Dept. of Plant Sclences } \\
\text { Univ. of Western Ontario } \\
\text { London, Ontario } \\
\text { Canada }\end{array}$ & $\begin{array}{l}\text { Peanut peroxidase } \\
\text { enzymes }\end{array}$ & $\begin{array}{l}\text { Composition, } \\
\text { linkage }\end{array}$ & 2 & $07 / 29 / 91$ \\
\hline
\end{tabular}


Appendix V: Cell Wall Polysaccharide/Oligosaccharide/Protocol Requests Received from September 1990-August 1991 
Appendlx V. Samples Prepared and Sent to Outslde Invesllgators, September 1990 - August 1991

Investigator Sample(s) Sent/Amount Date

Dr. Beat Keller

Eidg. Forschungsanstelt für

Lendw-Pflanzenbau

Zurich, Switzerland

Dr. Egon Mösinger

Sandoz Agro L.Id.

Crop Protection Research

Basel, Switzerland

Dr. Martin Parniske

Phillips-Universität

Fachberelch Blologie-Botanik

Marburg, Germany

Dr. Karl-Erik Eriksson

Department of Biochemistry

The University of Georgia

Athens, GA

Dr. Andrew Staehelin

Department of Biology

University of Colorado

Boulder, $\mathrm{CO}$

Dr. Keith Roberts

John Innes Institute

Norwich, United Kingdom

Dr. Paul J.J. Hooykaas

Clusius Laboratory

Department of Plant Molecular Biology

Leiden, The Netherlands

Dr. Vernon N. Reinhold

Department of Nutrition

Hanvard School of Public Health

Boston, MA

Dr. Thomas M. Zinnen

Plant Molecular Biology Center

Northern Illinois University

Dekalb, IL
$4 \mathrm{mg}$ active glucan from tobacco leaves

* 3-5 rng Pmg Pre-A glucan

$\approx 3-5 \mathrm{mg}$ Ping void glucan

$10 / 90$

$\approx 10 \mathrm{mg}$ Pmg void glucan

$10 / 90$

$250 \mathrm{ml}$ sycamore cell wall enzymes

(whole cell extract)

$10 / 90$

$300 \mathrm{ml}$ sycamore cell wall enzymes

(cell wall extract)

$2 \mathrm{~mL}$ MH 4.34

$2 \mathrm{~mL} \mathrm{CCC} \mathrm{8.10A3}$

$2 \mathrm{~mL} \mathrm{CCC8.2E6}$

$2 \mathrm{~mL} \mathrm{CCC} 8.12 \mathrm{H} 8$

$10 / 90$

$5.5 \mathrm{mg}$ sycamore extracellular xyloglucan

$11 / 90$

Mixtures of oligogalacturonides

(Pool 1, 3, 4)

Xyloglucan oligosaccharides

(SEPS XG7, SEPS XG9)

Xyloglucan oligosaccharides

(XG7, XG8, TXG9)

$11 / 90$

Fungal glucan preparation

$11 / 90$ 
Dr. John M. Labavitch

Department of Pomology

University of California

Davis, CA

Dr. Eugene Nestor

Department of Microbiology

University of Washington

Seattle, WA

Dr. Jacek Hennig

Waksman Institute

Rutgers University

Piscataway, NJ

Dr. Keith Roberts

John Innes Institute

Nonwich, United Kingdom

Dr. Jean Dénarié/Dr. Georges Truchet

Laboratoire de Biologie Moléculaire des Relations Plantas-Microorganismes

CNRS-INRA

Castanet-Tolosan, France

Dr. Jean Guern

CNRS/ISV

Gif Sur Yvette, France

Professor W.J. Lucas

Department of Botany

University of California

Davis, CA

Dr. Ann G. Matthysee

Department of Biology

University of North Carolina

Chapel Hill, NC

Dr. Enwin Heberle-Bors

Althanstrasse 14

Vienna, Austria

Dr. Jean Guern

CNRSIISV

Gif Sur Yvette, France

Dr. Jonathan Arias

Salk Institute for Biological Studies

Plant Biology Laboratory

San Diego, CA
$1 \mathrm{~mL}$ aliquots of hybridoma

$11 / 90$

CCC 8.2E6 and CCC 8.12H8

$1 / 91$

3 pools ( $3-4 \mathrm{mg}$ each) of

oligogalacturonides with differing

degrees of polyrnerization

$\approx 5 \mathrm{mg}$ void glucan elicitor

Hybridoma supernatants

(3 $\mathrm{mL}$ each)

Large and small oligogalacturonides

$2 / 91$

Sodium borotritide -

2/91

reduced tridecagalacturonide

$=1 \mathrm{mg} 13 \mathrm{mer}, 13 \mathrm{mer}$ modified by

treatment with uronic acid oxidase

$10 \mathrm{mg}$ void glucan

2/91

$=2 \mathrm{mg}$ sycamore extracellular

xyloglucan

$3 / 91$

Samples containing oligogalacturonides

$3 / 91$ of different size ranges

$12 \mathrm{mg}$ of pooled oligogalacturonides containing the rarige that are active

in potassium efflux assay

$=50 \mathrm{mg}$ void glucan elicitor

$\approx 5 \mathrm{mg}$ Pre-A glucan elicitor 
Dr. Friedman

$\approx 50 \mathrm{ml}$ sycamore suspension culture

Departinent of Biology

Marquette University

Milwaukee, WI

Dr. Mike Adams

Department of Biochemistry

$1 \mathrm{~g}$ sycamore cell walls

$5 / 91$

The University of Georgia

Athens, GA

Dr. Lars Liungdahl

Department of Biochemistry

$2 \mathrm{~g}$ sycamore cell walls

The University of Georgia

Athens, GA

Dr. Pressey

USDA

Russell Fissearch Center

Athens, GA

Dr. Keith Roberts

Jolin Innes Institute

Norwich, UK

Dr. Wolf-Dieter Reiter

Michigan State University

MSU-DOE Plant Research Laboratory

East Lansing, MI

Dr. Jean Guem

CNRSIISV

$\approx 14 \mathrm{mg}$ oligogalacturonides

$D P \approx 1.7$

$3 \mathrm{mg}$ sycamore RG-I

$5 / 91$

$1 \mathrm{mg}$ sycamore RG-1

$3 \mathrm{mg}$ sycamore RG-2

CCRC-M1-hybridoma supernatant, IgG

Gif Sur Yvette, France

Dr. Jor rathan Arias

Salk Institute for Biological Studies

$\approx 100 \mathrm{mg}$ void glucan elicitor

$\approx 12 \mathrm{mg}$ fraction $\mathrm{C}$ glucan elicitor

$5 / 91$

Plant Biology Laboratory

San Diego, CA

Dr. John Mundy

Carisberg Research Center

$\approx 8 \mathrm{mg}$ void glucan elicitor

$6 / 91$

Copenhagen, Denmark

Dr. Larry Griffing

Department of Biology

Texas A\&M University

College Station, TX

Alexei V. Babakov

Institute of Agricultural Biotechnology

Moscow, USSR

$8 \mathrm{mg}$ Pre-A glucan

$\approx 8.9 \mathrm{mg}$ Fraction $\mathrm{C}$ glucan

$1.1 \mathrm{mg}$ hepta- $\beta$-glucoside elicitor

$\approx 2 \mathrm{mg}$ void glucan elicitor 
Dr. Louise Brisson

Plant Biology Laboratory

Salk Institute

l.a Jolla, CA

Prof. Dr. Roland Bourrillon

Université Paris VII

Faculté de Nédecine Larib)oisiére Saint Louis

Laboratoire de Biochimie

Paris, France

Professor Nam-Hai Chua

Laboratory of Plant Molecular Biology

The Rockefeller University

New York, NY

Dr. Mike McNeil

Department of Microbiology

Colorado State University

Fort Collins, CO

Dr. Marguerite Kopp

CNRS

Sirasbourg, France $\approx 100 \mathrm{mg}$ void glucan elicitor

12 glycopeptide samples

$8 / 91$

2 oligogalacturonide samples

$8 / 91$

$10 \mathrm{mg}$ sycamore EPG-released material

$8 / 91$

$200 \mathrm{mg}$ Pmg cell walls

$8 / 91$ 

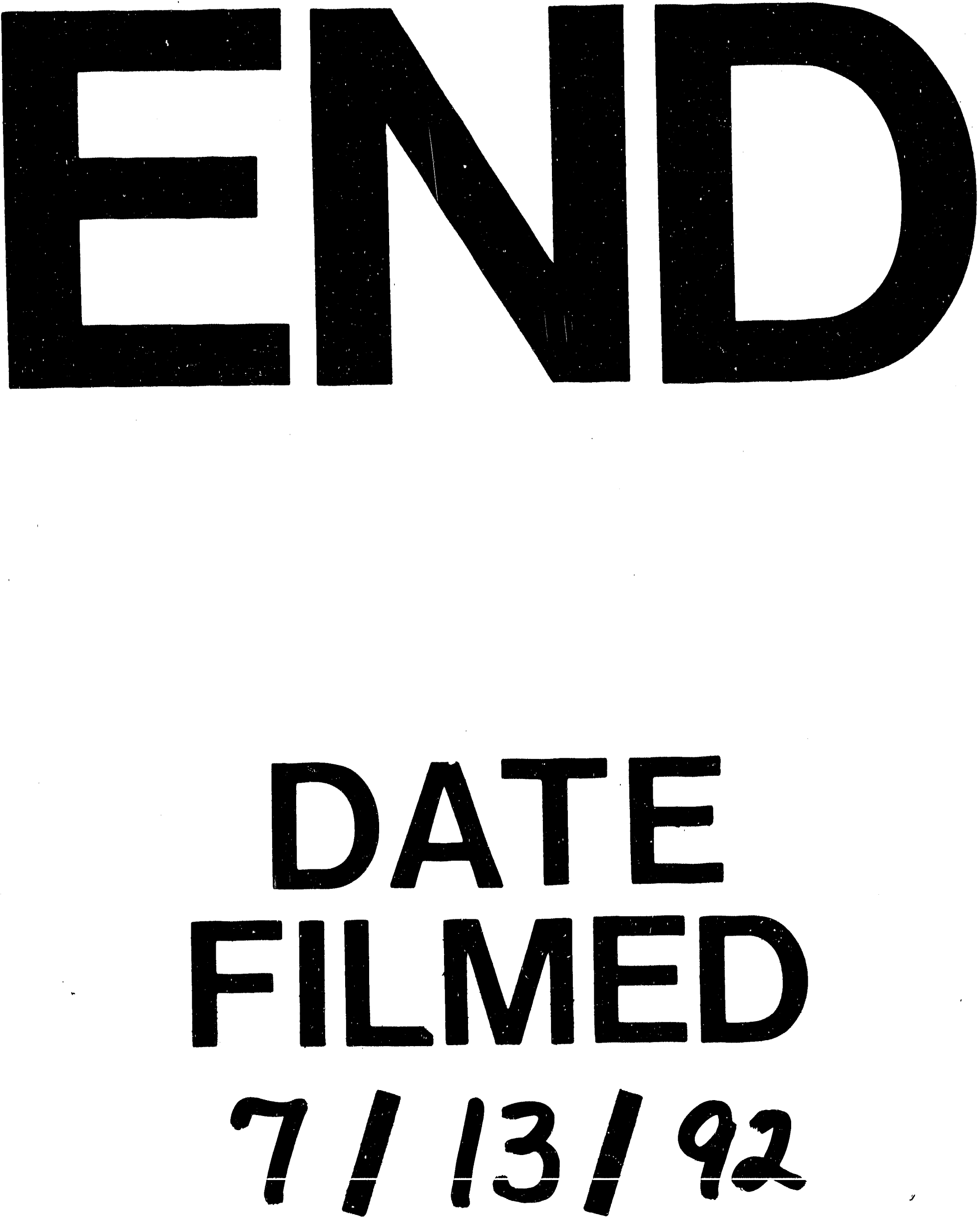
